


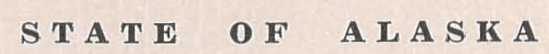

DE P A R T M E N T O F M I N E S

\section{Report \\ of the}

\section{Commissioner of Mines}

for the

BIENNIUM ENDED DECEMBER 31, 1958 


\section{DE'PARTMENT OF MINES STAFF ON DECEMBER 31, 1958}

Phil R. Holdsworth, Commissioner of Mines, Box 1391, Juneau James A. Williams, Mining Engineer, Box 1391, Juneau Martin W. Jasper, Mining Engineer, Box 2139, Anchorage Robert H. Saunders, Mining Engineer, Box C, College Wiley D. Robinson, Coal Mine Inspector, Box 2139, Anchorage Willow M. Burrand, Assayer-Engineer, Box 657, Nome Donald R. Stein, Assayer, Box C, College Ralph E. Pray, Assayer, Box 1408, Ketchikan Stephen P. Metzger, Assayer, Box 2139, Anchorage Cathryn A. Mack, Administrative Assistant, Box 1391, Juneau Jean L. Crosby, Mineral Analyst, Box 1391, Juneau

Dorothy C. Soley, Clerk-Stenographer, Box 1391, Juneau 
The Department of Mines

General Information and Activities

Assay Offices and Field Stations

Aield Investigations

Investigation

Safety Inspections

Cooperation with Federal Agencies

The Mining Industry

Production

Table I-Mineral Production of Alaska, 1956-1958

Figure 1-Annual Mineral Production, 1900-1958

Table II-Average Metal Prices as quoted by E. \& M. J. Prospecting and Exploration

Figure 2-Claims Staked by Division and Year .

Future and Needs of the Industry

Precious Metals

Base Metals

Nonmetallics

Coal

Radioactives

Oil and Gas

Employment and Accidents at Mines

Employment and Nonfatal Accidents

Fatalities

Table III-Employment at Mines, 1914-1958

Table V-Accidents and Employment, 1957-1958

Table V-Man-shifts Worked, Accidents, and Time Lost, 1912-1958

List of Active Mining Operations, 1957-1958 44

List of Active Coal Mines, 1957-1958

List of Active Oil and Gas Companies, 1957-1958 73

Lists of Publications Issued Since 1912 


\section{THE DEPARTMENT OF MINES}

\section{General Information and Activities}

The Territorial Department of Mines*, under the management and direction of the Commissioner of Mines, has charge of al matters affecting exploration, development and mining of the mineral resources of Alaska; the collection and dissemination of all official information relative to the mineral resources, mines, and mining projects of the State; and has charge of the administration of the laws with respect to all kinds of mining and mining safety.

The Department of Mines (TDM) conducts a continuing survey of the mineral resources and mining operations of the State and disseminates information in regard thereto with a view toward perpetuating and assisting prospectors and miners; safeguards the lives and health of miners; protects investors in the mining industry; and otherwise fosters and promotes the best interests of the mining, mineral, and related industries of the State.

For the purpose of directly and personally aiding miners and prospectors and stimulating mineral discoveries, the Department of Mines maintains four public assay and field offices in the State located at Ketchikan, College, Anchorage, and Nome. Mining engineers travel "into the bush" to give advice and help. Assistance is also rendered to mining people and others at the Juneau office.

In view of the extreme need for increased mining production in Alaska, the Department is exerting every effort within its means to obtain basic information on mineral deposits of possible commercial importance and to distribute this information to interested miners and venture capital. Much time is spent in all offices in giving advice and assistance to exploration parties, researchers, and engineers or geologists representing mining com-

*As this is written, Alaska has just become a State. Reorganization and renaming of the several Territorial Departments to form the new State governini are pending, but have not yet ben in this they will soon be outdated. 
panies who are looking for mining or invesment opportunities. Mining companies and investors outside of Alaska are contacted and urged to investigate Alaska's mineral possibilities. These efforts by the TDM have helped create a marked increase of venture capital expenditures in Alaska within the last three years. This increase has resulted in important discoveries.

The Department also works continually for needed changes in mining, land, and tax laws which will make new mining ventures easier to achieve.

Protection of investors is another field of endeavor in which the Department is very active. At the request of past, present, and prospective investors, various organizations and individuals are investigated and reported on as to their reliability, reputation, or methods employed. This is a distinct service to the legitimate operators as it helps maintain a good reputation for Alaskan mining in general.

The Department publishes a monthly mining news and information bulletin called the TDM Bulletin. It has been widely praised by all who have read it, and has many times received national recognition by the mining industry. Its primary aim is to keep Alaskan miners and prospectors informed on mineral and mining matters, but "outside" companies have found it useful to maintain Alaskan contacts. Even some of the top administrators in Washington, D. C. have used it to keep informed on Alaskan affairs. Circulation at present is nearly 1,500. Information circulars are also published as the need arises. Technical and informational papers are written for mining conventions and conferences to spread information on conditions and opportunities in Alaska.

The staff of the Juneau office of the Department includes Phil R. Holdsworth, Commissioner of Mines; James A. Williams, Mining Engineer; an Administrative Assistant; a Mineral Analyst; and a Clerk-Stenographer. Located in the Anchorage area are Martin W. Jasper, Mining Engineer; Wiley D. Robinson, Coal Mine Inspector; and Stephen P. Metzger, Assayer. Robert H. Saunders, Mining Engineer, and Donald R. Stein, Assayer, are stationed at College in the Fairbanks area. The Ketchikan office is presently operated by Ralph E. Pray, Assayer. The position of Assayer-Engineer at Nome is filled by Willow IM. Burrand. The TDII staff has been increased by only one person in the last six-year period.

Libraries of Alaskan publications issued by the U. S. Geological Survey, U. S. Bureau of Mines and the Atomic Energy Commission are maintained at the assay and field offices and the Juneau headquarters. These libraries are open to the public and, in addition to these publications, the Juneau office has collected much additional information on various properties throughout the State resulting from examinations and reports by engineers of the Department and others. The offices also maintain collections of classified rocks and minerals, including those of Alaskan origin, as a means of ready reference or identification by the prospector and miner.

Several thousand inquiries in regard to the mining industry and mining opportunities by visitors and by correspondence were answered during the biennium. Professional advice in the way of examinations and reports is offered to the prospector and miner by Departmental engineers. This service is offered to those who cannot afford the employment of a private consultant. Reports of examinations by TDM engineers for private individuals are for their information only, and results of same are only made public upon authorization by the property owners, which is usually given. Many requests for this type of advice were received and resulting examinations made by members of the Department staff. Services include making contacts between holders of mining ground and prospective purchasers, when requested. Geophysical exploration projects on a moderate scale are also carried out by Department engineers.

The Department's mineral analyst continues on a full-time basis the work on the complete bibliography and inventory of Alaskan mineral deposits authorized by the 1953 Legislature. During the project's first biennium, the work was done only when personnel could be spared from their regular duties. This project has been of great assistance to many individuals and mining company representatives who have come to the Juneau office in search of information on mining areas and properties for possible future operations. Although the work of detailed compilation is not complete, the project is sufficiently well organized so that 
nearly all information on specific areas or properties can be obtained in a few minutes. It should be noted here that the TDIM files of mineral information are organized so that all reports, maps, correspondence and data relating to area, prospects, or properties are filed according to geographical location in the State. The system of USGS quadrangles is used as a basis for the filing system. This makes an efficient arrangement, and eliminates almost entirely the possibility of accidentally missing important information on a particular property or area.

The Cental Recording function set up by the 1953 Legislature is continuing, and the claim location and assessment work affidavits are coming in regularly from the various U. S. Commissioners who are the recorders for their respective recording precincts. At the end of 1958 , there were a total of 16,209 documents in the files, 2,512 having been received during 1957, and 4,628 during 1958. These represent ownership and other information on an estimated 16,000 unpatented claims in Alaska, and is the only way in which records on unpatented mining claims can be efficiently filed. In addition to being cross-indexed under three headings, this information is also being incorporated into the above-mentioned mineral deposit inventory so that current ownership of prospects can be easily determined from one record. This system is a step ahead of the files at any of the other State mining departments, and several of the Western State mining department executives have expressed their interest in following Alaska's lead in this field. A discussion and illustration of the trends of claim staking as indicated by the documents coming into Central Recording is included under "Prospecting and Exploration."

The Department of Mines is responsible for the Coal Miners Examining Board. The Commissioner of Mines and the Coal Mine Inspector are chairman and member respectively. Two other members are chosen from the industry by the industry: one from the operators and one from the coal miners' union. The purpose of the Board is to examine applicants who wish to obtain supervisory positions in the coal mines to determine if they have suficient experience and knowledge for the safety of the men who work under them. A total of 28 first class and 17 second class certificates have been issued since the Board's creation in 1953.
Chapter 129 enacted by the 1955 Legislature put the Department into the prospectors' equipment rental business. Under the provisions of this Act, there were purchased for rental to prospectors eight diamond core drills, sixteen Geiger counters, and sixteen Mineralights, which were divided equally among the four judicial divisions. A gasoline jack hammer was purchased later. This equipment has been rented out to many prospectors, helping their prospecting ventures greatly. Since the Act made no provision for disposition of the rental money, it has been regularly turned into Alaska's General Fund.

The TDM was given the task of examining and licensing explosives handlers in the construction industry in 1955. The law requires that all men hired for the purpose of detonating explosives must be certified by the TDM as fit and competent, and that the TDI must determine their fitness by examination. Miners, prospectors, and self-employed persons are exempt. Although it is felt by the Department that this function should more properly be administered by the Department of Labor, since the Act was passed expressly for the benefit of construction workers, the TDM has nevertheless done the work to the best of its ability without an increase in personnel. Explosives handlers' examinations are given at all stations and in other locations as field trips on regular business permitted. Also, trips are made to outlying communities to give examinations when the demand from a number of applicants justifies the travel, lbut this is kept to a minimum because of the extra expense involved. Examinations have been given to 326 applicants, of which 314 were suscessful and received certificates of fitness. A fee of $\$ 5.00$ is charged for each examination, and the receipts are turned into the General Fund.

The 1957 Legislature passed a law creating a Prospector Assistance Program to be administered by the Department. Since the funds for the program were not available until July: of 1957 , the program was not started until 1958. The results for the first year are not encouraging and show that there is little demand from truly quallified prospectors for this type of assistance. The law requires that a person must prospect for at least 30 consecutive days and shall be allowed a maximum of $\$ 200$ for transportation for the trip and $\$ 100$ per month for supplies while "in the bush." Only bona fide residents of Alaska are eligible, and in 
case of a surplus of qualified applicants, lots are drawn to determine who shall be on the program. It was decided to put 16 prospectors on the program in the 1958 season, but of these, only three completed their prospecting ventures as planned and two completed only part of the work they indicated on their applications would be done. For various reasons, the remainder of the chosen applicants did not go out at all. This program will be operated again in the season of 1959 , but funds for further assistance after 1959 will probably not be available.

Chapter 40, SLA 1955 created the Oil and Gas Conservation Commission and included the Commissioner of Mines as a member and director. The Commissioner has been very active in directing this body and formulating policies for future regulation of oil production in regard to conservation. The stenographic and clerical work for the Oil and Gas Conservation Commission has been handled by the Juneau TDM staff.

As a result of the Richfield oil strike on the Kenai Peninsula on July 23, 1957, Alaska was admitted as a full member to the Interstate Oil Compact Commission. The Commissioner of Mines is Alaska's official representative to the IOCC, attends their meetings annually, and keeps them informed on oil matters pertaining to Alaska as well as receiving information of lbenefit to Alaska.

The 1957 Legislature created the Alaska Land Board to direct and set policies for the new Alaska Department of Lands. Certain department heads are members of this Board, and the Commissioner of Mines has been serving as its Chairman. This has created considerable work for the TDM staff at Juneau, where, like that of the Oil and Gas Conservation Commission, the clerical and stenographic work for the Board is done.

The Commissioner of Mines also serves as a member of the Alaska Resource Development Board.

\section{Āssay Offices and Field Stations}

The assay offices and field stations of the Department of Mines at Ketchikan, College, Anchorage and Nome continued to perform analyses and mineral determinations during the biennium. This service is offered free of charge to prospectors and miners and serves to encourage the search for minerals in the
State. The following tabulation compares the number of assays made during the past four years:

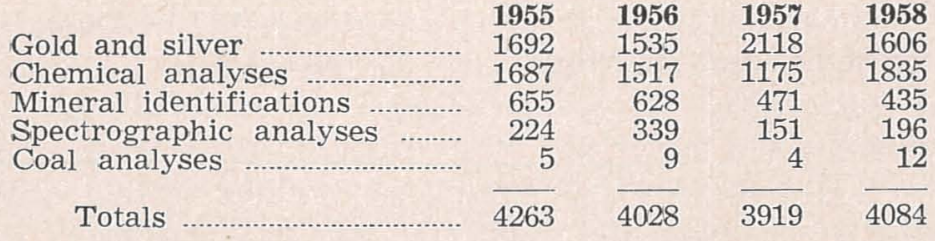

Assay offices and field stations of the Department are now satisfactory and adequate with the exception of the situation at College. As reported for several preceding years the College Assay Office has for many years been housed in quarters that are entirely inadequate and positively unsuitable for the large work load of the Fourth Division. It is in the basement of the old University power plant. This building has been condemned, and will be razed as modernization of the campus continues. For these reasons, a move of this office is imperative. It is hoped that funds will be forthcoming from the first State Legislature to make this move, and to provide space in the same new quarters for the Department's mining engineer stationed at College. This will allow closer cooperation between the assayer and engineer and provide better service to prospectors, miners, and the general mining-minded public than is presently possible.

The assay office at Ketchikan was moved during the biennium, a move that was necessary because of a request by the City of Ketchikan, which owned the former location. The TDM was fortunate in obtaining an old building which could be remodelled into a suitable assay office and laboratory. The remodelling is practically complete and the office is functioning well.

The Nome Assay Office operated satisfactorily throughout the biennium after the completion of the remodelling of the old building there in the previous biennium. The Assayer stationed at Nome also serves as a field engineer for the Second Division Though the building is owned by the TDM, the office space is shared with the Department of Taxation personnel stationed there, resulting in a saving on expenses to both agencies.

The TDM building at Anchorage is modern and adequate. It contains the offices of the mining engineer and coal mine 
inspector as well as the assay laboratory. Offices of future petroleum engineers and geologists will probably be there too.

Two special types of analyses are offered by the Department: spectrographic and fluorimetric. The spectrograph is located at the College office. It provides a means of determining quickly all the major and minor and most of the trace elements in an ore sample. This quite often results in finding certain valuable elements in a sample that otherwise may be accidentally missed by ordinary assay methods, and hence is a valuable addition to the TDIM services.

The fluorimeter is at the Ketchikan office. This instrument is used to determine the actual amount of uranium in a sample. With Geiger or scintillation equipment, one can determine the relative total amounts of radioactivity in samples, but not the portion of the total that is caused by uranium only nor the amount that is caused by the other radioactive elements that are nearly always associated with uranium. The fluorimetric process takes the guesswork out of radioactive assaying.

Coal analyses are made at the College assay office. A charge is usually made for this particular service.

\section{Field Investigations}

Field examinations and technical assistance were given by members of the Department of Mines staff to those requesting this service. Examinations were made, and reports written or professional advice given, on mining properties and prospects throughout Alaska. Minerals concerned in these examinations were copper, iron, nickel, lead, gold, mercury, vermiculite, barite. coal, tungsten, chromite, and others. Reports and recommendations were made to mining companies and other potential purchasers of mining prospects on behalf of property holders, and assistance was given in a few of the negotiations. Technical advice was given at active mining operations, when requested, on mining methods and problems. Exploration drilling projects were assisted. The commercial possibilities of undeveloped coal beds were investigated.

\section{Safety Inspections}

In addition to geological and other types of examinations, the
TDM engineers also examined properties visited for safety conditions. Other properties were visited for safety reasons only. Tunneling projects were also visited for the purposes of safety inspections and enforcement, since by law all underground work is under the jurisdiction of the Department even though not connected with mining. The Commissioner of Mines visited oil well sites.

The Department is jointly responsible with the U. S. Bureau of Mines for the inspection and enforcement of safety conditions in Alaskan coal mines for the protection of the coal miners. Joint inspections with the Bureau safety inspector are made. Also, the regular monthly inspections of the coal mines by the TDM Coal Mine Inspector continued. The union-sponsored safety committees continued to work with the Department to keep the miners "safety conscious."

\section{Cooperation with Federal Ägencies}

The TDM and the U. S. Bureau of Mines have in effect a formal signed agreement for the mutual cooperative interchange of information. This eliminates duplication of effort and is a saving of time and money. There has also been a free exchange of information with the U. S. Geological Survey and the Atomic Energy Commission.

Since the U. S. Bureau of Mines uses a system of mining district designations for its statistical reporting, and the U. S. Geological Survey now bases its geological information on its quadrangle system, the Department of Mines has adopted both systems in order to facilitate exchange of information with both agencies. In the text of this report, mining district designations are used in describing mining operations, etc., because the water shed boundaries of the districts seldom divide mining areas. In the appended tabulated list of active mining operations, both district and quadrangle designations are used in order that interested persons may also become familiar with the locations with respect to the USGS quadrangle maps which are published for the entire State and widely used.

The U. S. Geological Survey sends to the Department copies of "open file" reports pertaining to Alaska that are not available for public distribution, but which may be consulted at TDM 
offices. The USGS also keeps the TDII appraised of its field work plans and other matters of importance so that the TDIM can act accordingly in the best interests of the industry.

The Bureau of Land Management and the Forest Service have cooperated to the best of their ability in supplying information on the status of mineral lands and claims when requested. The Forest Service has received much information and help from the TDM in gathering information on mining claims and mineralized areas for their various programs, including the Public Law 167 program, which has to do with determining surface rights on unpatented claims.

In the matter of protection of the investor, there is good cooperation and exchange of information between the TDM and the Federal Securities Exchange Commission.

\section{THE MINING INDUSTRY}

\section{Production}

Alaska's total mineral production, dollarwise, for the 19571958 biennium, increased by more than $4 \%$ over that of 1955-1956. This increase for the biennium was caused by larger production of mercury, which was more than doubled; stone, which was tripled; and uranium, produced in 1957 only. Coal, gold, and sand and gravel held about even between the two biennia. Though production for the biennium was a high point, the yearly trend is different and shows a drop of nearly $30 \%$ in 1958 from that of 1957. See Table I and Figure I. Production in 1957 reached the highest peak since before the War, but in 1958 it dropped to the lowest point since 1951. This large drop from 1957 to 1958 was chiefly because of the decline in production of coal, stone, and sand and gravel, in addition to the complete lack of uranium and chrome production in 1958. Production of mercury and platinum also dropped. Responsible, too, for the overall decline in value was the drop in unit values (prices) for nearly everything except gold. 
TABLE I

Mineral Production of Älaska, 1956-1958

\begin{tabular}{|c|c|}
\hline Antimony & short tons \\
\hline Chromite ................... & short tons \\
\hline Coal, bituminous & short tons \\
\hline Gold & troy ounces \\
\hline Lead ....... & ......short tons \\
\hline Mercury & flasks 76 lbs. \\
\hline Platinum & ...troy ounces \\
\hline Sand and gravel & ......short tons \\
\hline Silver & ....troy ounces \\
\hline Stone ........................... & ....short tons \\
\hline $\begin{array}{l}\text { Uranium } \\
\text { Undistributed (3) }\end{array}$ & \\
\hline
\end{tabular}

Total

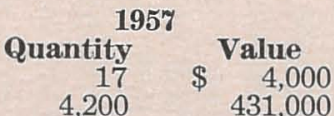

$$
\begin{aligned}
& \begin{array}{r}
431,000 \\
7,296,000
\end{array} \\
& 7,541,000 \\
& 3,000 \\
& 842,338 \\
& 215,467 \\
& 5,461 \\
& \begin{array}{c}
\text { (2) } \\
6,096,000
\end{array} \\
& \begin{array}{r}
096,000 \\
28,862
\end{array} \\
& 528,000 \\
& \begin{array}{r}
528, \\
\text { (2) }
\end{array} \\
& \begin{array}{r}
1,349,00 \\
(2)
\end{array} \\
& \text { (2) }
\end{aligned}
$$

1958 (1)
Quantity

\section{$732,000 \quad \$ 6,350,000$}

$215,000 \quad 7,500,000$

(2)

(2)

(2)

(2)

$4,100,000$

28,000

273,000

26,000

955,000

$1,246,000$

$\overline{\$ 21,077,000}$

(1) All figures for 1958 and undistributed figures for 1957 are preliminary and subject to revision.

(2) Values included with "Undistributed" to avoid disclosing individual company incomes.

(3) Includes gem stones, platinum uranium, antimony, and mercury.

Note: Above statistics prepared in cooperation with Alvin Kaufman, U. S Bureau of Mines, Juneau, with the extion of the coal value for 1958 and the undistributed for 1957 and 1958, which are presented on authority of the TDM only. Note also that sand and gravel are not true minerals, but are carried by the U.S.B.M. for statistical reporting of mineral production throughout the U. S.

FIGURE I.

Annual Mineral Production, 1900-1958

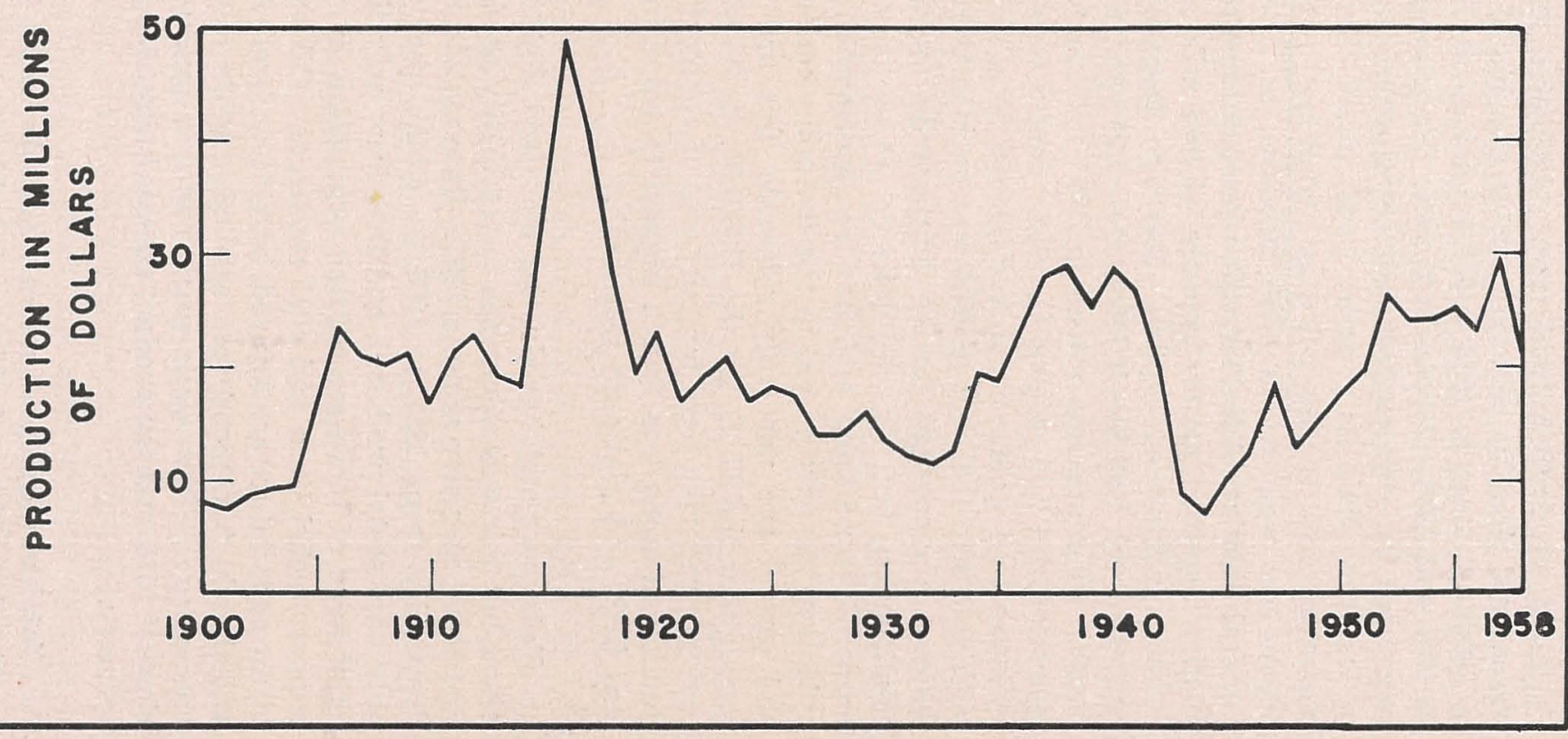


Gold production held steady between 240,000 and 250,000 ounces per year for several years to the end of 1955. It dropped to 209,000 ounces in 1956 and has held at around 215,000 ounces in 1957 and 1958. It may hold near this average for a few more years, but by 1963 or 1964, gold production in Alaska will drop to less than half its present level unless there are unforeseen improvements in the price or economic conditions. Chrome production was nil in 1958 because of the closing of the General Services Administration purchasing program. Coal production declined mostly because of two mild winters and large existing military stockpiles. Mercury dropped because of difficulties at the Red Devil Mine, the only significant mercury producer. Uranium was mined in 1957 for the first time, but the operation did not resume in 1958. Silver is produced only as a byproduct of gold. Sand and gravel was higher in 1957 than both gold and coal, but in 1958 was back in third place again. Its decline is accounted for by temporarily decreased government construction activity, an activity which is not dependent on economic conditions and has no connection with the mining industry. As pointed out in the footnotes beneath the table, sand and gravel are not truly minerals, but are reported as such throughout the U. S. by the U.S.B.M. in its statistical work, so they are reported here for purposes of comparison. In 1958, production of stone was fourth highest in value in Alaska, mercury was fifth, and platinum was sixth.

Total base metal production increased slightly during the biennium, but this was solely due to the highly productive year of the Red Devil mercury mine in 1957. Base metals, of course, declined drastically from 1957 to 1958, in which year mercury was the only base metal produced, and that from only the one mine. The chief hope of increased mining production in Alaska lies in her copper, nickel, iron and coal resources. Oil and gas production in the near future are assured, barring unforeseen economic upsets and harsh tax measures applied before the industry gains momentum. Two wells were running production tests at the close of 1958, and the production was being shipped to a California refinery.

Total mineral production in Alaska since 1880 now adds up to $\$ 1,184,301,000$. Of this total, gold has accounted for $62 \%$, or
$\$ 729,622,000$. Copper production has created $19 \%$ of the overall total, and totals $\$ 226,890,000$, although no copper in significant quantities has been produced in Alaska since 1938 when the famous Kennecott Mine shut down. Coal production has reached a total of $\$ 85,684,000$ and accounts for $7 \%$ of Alaska's overall total.

\section{TABLE II}

A verage Metal Prices as Quoted by E. \& M. J.

\begin{tabular}{|c|c|c|c|c|}
\hline 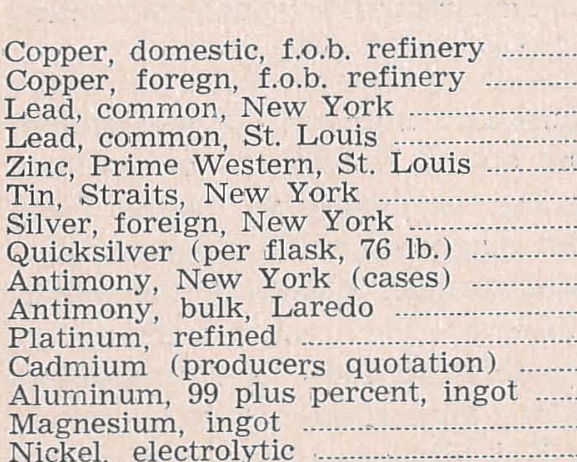 & $\begin{array}{r}1956 \\
41.82 \\
40.43 \\
16.01 \\
15.81 \\
13.49 \\
101.41 \\
90.83 \\
\$ 259.92 \\
36.47 \\
33.00 \\
\$ 103.90 \\
170.00\end{array}$ & $\begin{array}{r}195 \% \\
29.58 \\
27.16 \\
14.66 \\
14.46 \\
11.40 \\
96.26 \\
90.82 \\
\$ 246.98 \\
36.59 \\
33.00 \\
\$ 89.45 \\
169.65 \\
27.52\end{array}$ & $\begin{array}{r}1958 \\
27.76 \\
25.12 \\
12.11 \\
11.91 \\
10.31 \\
95.13 \\
89.04 \\
\$ 229.06 \\
33.08 \\
29.49 \\
\$ 64.93 \\
152.30 \\
26.89\end{array}$ & $\begin{array}{r}28.60 \\
26.98 \\
13.00 \\
12.80 \\
11.50 \\
98.38 \\
89.88 \\
\$ 220.00 \\
32.59 \\
29.00 \\
\$ 52.00 \\
145.00 \\
27.30 \\
35.25 \\
74.00\end{array}$ \\
\hline
\end{tabular}

In studying the production curve shown in Figure 1, several things should be kept in mind: (1) the curve represents only the dollar value of each year's production, (2) the price of gold increased from $\$ 20.67$ to $\$ 35.00$ per ounce in 1933 , (3) although pold represents $62 \%$ of Alaska's total production since 1880 , it is currently only 30 to $35 \%$ of the yearly production, and (4) while sand and gravel production was negligible and coal production slight before the War, they each have represented from 25 to $35 \%$ of Alaska's production for the past several years.

\section{Prospecting and Exploration}

The number of individual and independent prospectors in the field continues to decline since the big uranium excitement in 1955. Organized prospecting by mining companies and syndicates reached a peak in Alaka in 1957, then declined moderately in 1958 following a serious drop in metal prices. It is expected that prospecting will continue on about the same level in 1959 as in 1958, although presently strengthening metal markets may increase the overall exploration efforts. It is an unfortunate feature 
of the mining industry that prospecting and exploration budgets are nearly always slashed in times of poor market conditions. Of the independent prospectors, only a relative handful of serious professionals are active for a significant period of time each summer. A large number of the "weekend" variety make short trips, but many of these have scant prospecting knowledge and experience. The poor response to the first year's Prospector Assistance Program, as related earlier in this report, is indicative of the small interest in full-time independent prospecting in Alaska. Also, the demand for the Department's rental prospecting equipment has been very slow for the past year.

The largest and most enthusiastic number of independent prospectors appear to be working out of Ketchikan, as has been the case for several years. During the past year, two of them purchased newly-developed aerial magnetometers and are flying them all over that section of Southeastern Alaska in the search for more iron deposits. One of these prospectors has made a very favorable-appearing discovery by this method. The prospectors of that area formed the Ketchikan Claim Holders Association in 1957. The TDM Assay Office in Ketchikan has been particularly valuable to the prospectors there in helping them with their mineralogical and other problems.

Anchorage is also an important center for prospecting activities. Several hundreds of visitors interested in some phase of mining or prospecting are accommodated by the TDM personnel there every year.

Although mining company prospecting was at a peak in 1957, the year 1958 was by far the most significant for discoveries made. In fact it was the best season for finding hitherto unknown deposits for many years. Nickel and copper discoveries of apparent major proportions were made in Southeastern Alaska, a significant mercury discovery was made in the Kuskokwim country, and an apparently large iron deposit was found in the Dillingham area. This latter deposit was found by the Humble Oil and Refining Co. while doing aerial magnetometer work in looking for indications of oil structures. No outcrops were visible, but drilling through the overburden at the location of the magnetic anomaly proved the presence of the iron. A total of 815 claims were staked there by Humble. These new discoveries prove the point that the TDM has made again and again, that there are valuable "hidden" mineral deposits in Alaska yet to be discovered.

Important new iron reserves have been calculated for a large deposit in the Bradfield Canal area, between Wrangell and Ketchikan, as a result of further exploration in 1958. There have been more exploration drilling projects during the biennium than during any other time since the War. A major coal exploration project was launched in 1958. A swing to the use of helicopters and geophysical and geochemical methods by prospecting crews has been more noticeable during the biennium than before. Specific exploration projects are mentioned later under the appropriate mineral heading.

Records received from Mining Recorders throughout Alaska indicate the yearly number of claims staked and claims for which assessment work is recorded to be as follows:

$\begin{array}{lllllll} & \mathbf{1 9 5 3} & \mathbf{1 9 5 4} & \mathbf{1 9 5 5} & \mathbf{1 9 5 6} & \mathbf{1 9 5 \%} & \mathbf{1 9 5 8} \\ \text { Claims staked } & \mathbf{1 2 8 6} & 1811 & 1821 & 1990 & 1410 & 2200 \\ \text { Assessment work } & . .5774 & \mathbf{6 1 7 9} & \mathbf{6 5 0 5} & \mathbf{6 8 6 6} & \mathbf{7 3 1 8} & \mathbf{7 5 0 0}\end{array}$

It can be seen that the number of claims staked in 1958 would be the lowest since 1953 were it not for the group of 815 Humble iron claims. Minerals for which the largest numbers of claims were staked during the biennium are the following in the order of their importance: iron, placer gold, copper, lode gold, nickel, limestone, silver-lead, and mercury. As in past biennia, the large numbers of gold claims staked continue to be surprising in view of the unfavorable gold mining conditions. Figure 2 is a graph showing the trends of the numbers of claims staked in each of Alaska's four Judicial Divisions for the past six years. The 1958 figures shown in this graph and the preceding table are estimates based on past experience on the time lag in receiving the documents. Claim staking in the Fourth Division shows a moderate and steady increase for the past three years, though it is noted that more than half of the claims staked there each year have been gold placer. Decreases have occurred for the past two years in the First and Second Divisions. Claim staking would have held about level in the Third Division during 1958 except for the Humble stakings, which caused the sharp rise in that curve. 


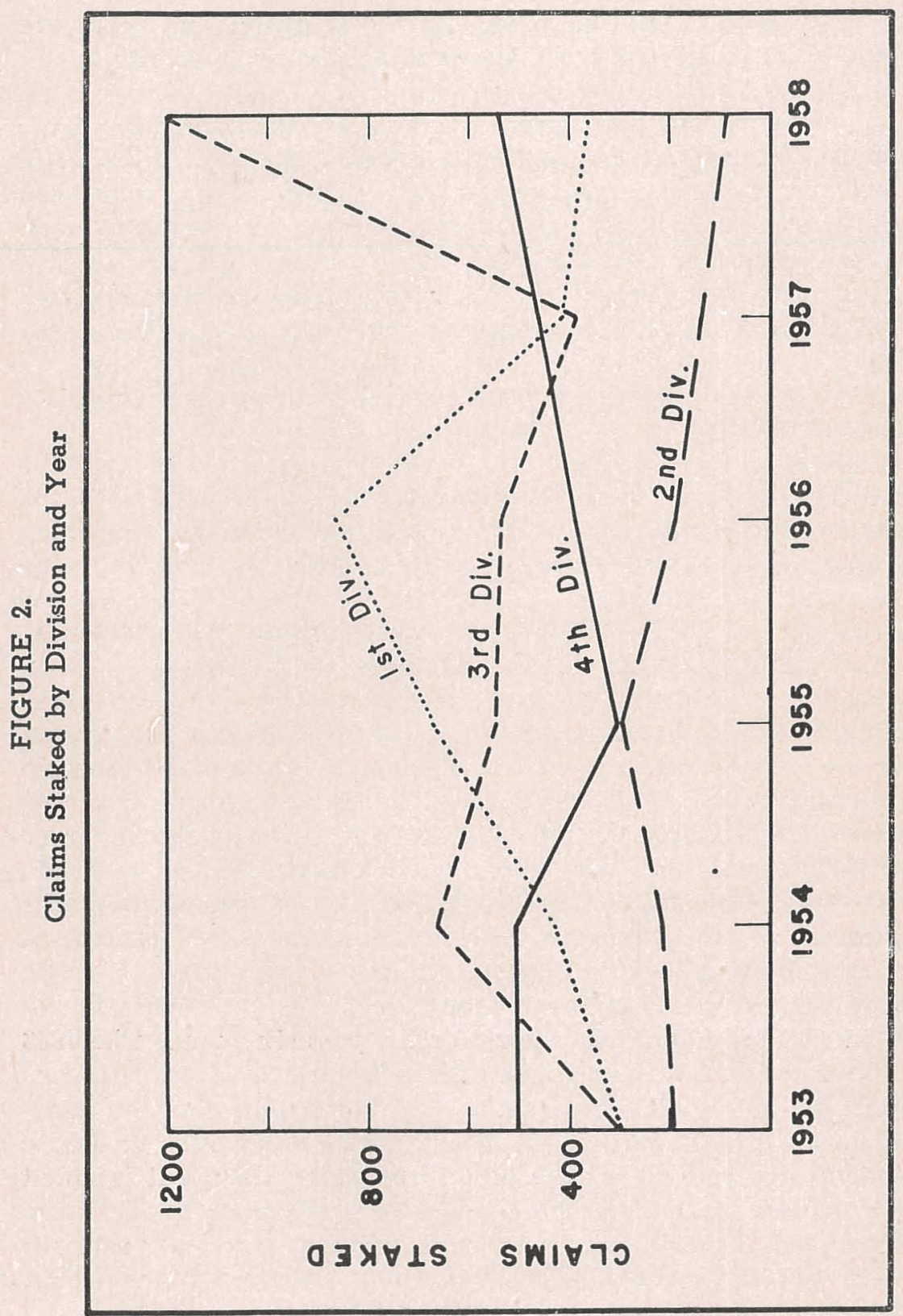

Three changes in mining law have been made during the biennium that are of particular interest to prospectors and claim holders: (1) the annual deadline for completion of assessment work has been changed from July 1 at noon to Septemiber 1 at noon, (2) geological, geophysical, and geochemical work on claims can now be counted as assessment work under certain prescribed conditions, and (3) in Alaska, claims for which assessment work has not been recorded at the end of the six-months period following the end of the assessment work year shall be considered abandoned and open to location by others. Further information. on these matters can be obtained by writing to the Juneau office of the TDM. Of interest also is the new Federal Office of Mineral Exploration which has just been set up to replace the old DMEA for financial assistance to exploration projects. OME for Alaska will be administered at the Spokane, Washington office of the U.S.B.M.

As is well known to everyone in Alaska, oil exploration has increased fantastically during the biennium. Many millions of dollars were spent by oil companies, both large and small, which were active in Alaska. During the biennium, there were 12 wells completed or being drilled. In 1958, 17 companies placed geological and geophysical crews in the field, and used more than 50 helicopters.

\section{Future and Needs of the Industry}

It must be reported once again that gold mining is disappearing from the Alaskan scene because of the fixed price of gold and the continual inflationary spiral of operating costs. Government and defense construction, which has had the largest part in causing increased costs and wages in Alaska, is finally recognized here as a permanent Alaskan feature. Technologies of weapons and communications are advancing so rapidly that before a defense or communication system is completed, it is outmoded and another one must be started. Although it will be noted that gold production seems to be fairly well sustained in the face of a diminishing number of gold mining operations, there is positive evidence that this production will be cut to less than half in a few years under the present economic trends.

Coal mining is suffering from inroads made by oil in capturing portions of the Alaskan fuel market. Also, if and when atomic 
power reactors are installed in Central or Interior Alaska, coa production will really be cut drastically. Hydro projects are also under discussion. A bright spot in the future is the Japanese export possibility. Investigations are underway which may lead to large exports of Alaskan coal for the Japanese steel industry.

In spite of the current market slump, the future of base metals in Alaska appears better now than at any time since the War. This is due to the recent discoveries of apparent major ore bodies and the increasing interest of the Japanese in our large iron deposits. Production of the iron deposits held by the large steel concerns will probably not be accomplished as soon as those in the hands of the smaller more aggressivee companies who have their sights on foreign market. Hopes are also high for early production of a large copper deposit in the Kobuk country now being drilled, and possible good results from the drilling of the large nickel property on Yakobi Island in Southeastern Alaska.

As nearly always, the mining industry needs more prospectors in the field, but more and more, as the grass-roots deposits are harder to find, the prospector needs a thorough knowledge of geology and mineralogy. If he can take advantage of the modern geophysical and geochemical methods available today, so much the better. The man on foot is still indispensable for most discoveries, and new discoveries must be made for the mining industry to grow, or even hold its own.

Huge parts of Alaska continue to be withdrawn, or be requested by Federal agencies for withdrawal, from prospecting and mining. Withdrawn areas, of course, are detrimental to the future of Alaskan mining, and are not necessary for the stated purpose of the withdrawals, as far as mining is concerned. It has been shown many times that mining and petroleum production can be carried on with no damage to the wilderness aspect, scenery, wildlife or other desired features of the surrounding country that the withdrawal is intended to preserve. When an area is closed to prospecting, there is no telling what deposits of strategic minerals may remain undiscovered there that might be of great help to the nation, and also to Alaska in increased revenues and population.

The mining industry still needs a means of obtaining the right to develop the many old patented claims in Alaska that have no legal owners. The Land Registration Law was to have cured this ill, but the legal procedures have slowed its workings down to the point where the law is not effective in making the old patented claims available to those who wish to explore and develop them. A nominal property tax would solve the problem.

Of prime importance is the need for a real incentive that can be offered to investment capital to attract it to Alaska's mineral resources. Part of this incentive would be a tax structure favorable to prospective investment capital. Alaska was quite generous in this respect when in 1953 a $3 \frac{1}{1} 2$-year mining tax exemption was granted to all new operations. But the Alaska tax is small in comparison to the Federal tax. If the U. S. would follow the example set by the Dominion of Canada in this matter, the effect would soon be shown in an increase in Alaskan mining. Canadian mining has shown a phenominal growth since the War, and American capital is going into these Canadian developments by the billions of dollars. One Canadian province-British Columbia made the mistake of passing some restrictive taxes against mining in 1957, only to see a large number of producing mines and exploration projects shut down practically overnight. It is reported that the mistake is now in the process of being rectified.

\section{Precious Metals}

Alaska's lode gold mining is practically nil. A few small intermittent operations of not more than 3 or 4 men are all that are active. Yelinore, Inc., did a little producing at the old Yellowband Mine in the Bremner area of the Nizina District, and Ed Toussaint of Fort Yukon built a mill and continued other preparations to mine the gold bearing quartz of the Summit claim in the Chandalar country. Wilson and Drake mined at Ester Dome in 1957, and the Fairbanks Mining Co. of Alaska performed explora1. worked at the Flume Creek mine in the Eagle District, but did not produce. Some work was done in a gold mine within the city limits of Seward and at the old John Dryer mine along the Seward Highway. The famous huge Alaska Juneau mine is now selling its equipment and machinery for use elsewhere and scrap.

Placer gold mining is still caught in the same squeeze between the fixed price and increased operating costs. In addition to these two factors, the ground being mined is getting poorer as the 
seasons go by. Statistics gathered by the U.S.B.IV indicate that the average ground worked in 1955 was worth $62 \mathrm{c}$ per cubic yard, while in 1956 and 1957 the average values were $46 \mathrm{c}$ and $44 \mathrm{c}$ respectively. As noted earlier in this report, gold production, though holding fairly steady in spite of fewer operators, will be cut to less than half in a few more years, barring unforeseen changes in the economic situation. This statement is predicated upon the public announcement of Alaska's largest producer, the U.S.S.R.\&M. Co., that it does not anticipate continuing its two large operations (Fairbanks and Nome) beyond 1963 or 1964

A trend has been noted among the nonfloating placer plants to the use of mobile elevated sluice boxes on wheels with various mechanisms to allow greater flexibility and efficiency of operation. Several operators investigated the possibilities of rubbertired tractors or loaders in the place of bulldozers, hoping for lower operating and maintenance costs. Some of the placer operations will be mentioned here, and a complete list of active operations is included later in this report.

In the First Division, the only placer activity was further working of the Alaska Juneau mill tailings by Howard Hayes.

In the Second Division the Lucky Syndicate put their purchased dredge into operation in the Kougarok. Jack Bullock of Kotzebue purchased the operation of Havenstrite at Candle, and Parker and Raymond, previously of the Circle District, mined there. Pat Bliss was the only operator in the Koyuk District, and Eugene Tetinek likewise in the Marshall District. The U.S.S.R.\&M Co. operated their three dredges in the Nome area and Lee Brothers continued with one on the Solomon River. Kougarok Freight and Mining Co. did not dredge on Buster Creek in 1958. Edwards and France used a loader on their nonfloat operation on the Solomon River. C. E. "El" Stout remained the only active placer operator in the Shungnak District.

The Third Division's most active placer camp is the Yentna District. Several operations have started and stopped there, and others have changed hands, but little production has resulted. Hobb Enterprises had a good year on Slate Creek in the Chistochina in 1957, but in that district, little else happened. About the only other placer activity in the Third Division of particular interest was a short-lived 20-man operation on Dan Creek in the Nizina in 1958.
In the Fourth Division, the U.S.S.R.\&M. Co. operated six dredges in the Fairbanks District during 1957, and seven in 1958. Dredge No. 3 at Chatanika began digging after an idle period of several seasons. Dredge No. 6 was moved from Gold Hill to Sheep Creek in early 1958. Chatham Creek Mining Co. moved from Chatham Creek to Last Chance Creek in 1958, and the Wolf Creek Mining Co. moved to Fish Creek the same year. Olive Creek Mines moved from that creek to Little Eva Creek near Ester. The U.S.S.R.\&M. Co. dredged in the Hog River area with the dredge brought from Livengood, and continued preparations for dredging at Chicken in the Fortymile. Also in the Fortymile, Bruce and Cunningham started a new operation on Mosquito Fork and George Gillbertson did likewise. In the Koyukuk, Louis Koshalk and Associates started a new operation on Crevice Creek and Miller, Lindgrin, and Atwood a new one on Sheep Creek. Yukon Placer Mining Co. discontinued operations at Livengood. Other districts remained about the same.

\section{Base Metals}

Though no production has yet resulted - and may not for several more years - Alaska has made progress toward a base metals industry during the biennium. The most important advances have been mentioned earlier, but they will be elaborated on here, together with other base metal information.

Iron. As in the previous biennia, the search for new deposits was confined mostly to Southeastern Alaska because of the need for cheap transportation for that type of ore. Among the favorable bodies of magnetite are those at Klukwan, Port Snettisham, Union Bay, Duke Island, Bradfield Canal area, and several on Prince of Wales Island. In addition there is now the new discovery of Humble Oil and Refining Co. near Dillingham, discussed earlier. The Klukwan deposit is being drilled and sampled by Columbia Iron Mining Co., a subsidiary of the U. S. Steel, who also operated a pilot concentrating plant there in 1957. Most attention so far at Klukwan has been given to the alluvial portion of the deposit, which contains hundreds of millions of tons of material, but there is also considerable lode iron above the placer. More drilling and sampling has been done by Fremont Mining Co. at Port Snettisham on their claims and those of W. S. Pekovich of Juneau, and some exploration has been continued on Columbia's 
property at Union Bay near Ketchikan. Mt. Andrew Mining Co. drilled for both full seasons on iron properties on Kasaan Peninsula of Prince of Wales Island, and also investigated others. The relatively new deposit in the Bradfield Canal area is on the North Bradfield River. Geophysical work has been done on it and drilling is planned.

Copper. The Prince William Sound, Nizina, and Ketchikan Districts seem the most promising areas for future production of copper, but it might come from the far north Kobuk country first. Bear Creek Mining Co., Kennecott exploration subsidiary, has been drilling a large and promising copper property north of the Kobuk River for two years. Late in the biennium, an option was taken on the Moose Creek copper show north of Palmer, and an exploration program there seems imminent. Large areas are being covered in various parts of Alaska by geochemical methods for copper. A prospecting group financed by Canadian mining interests staked a large number of claims on a promising copper show in the Juneau district. Favorable areas in the Nizina and Strelna areas have received attention in the past few years, particularly in 1957. The Maclaren River property near the new Denali Highway did not get into production, though some underground work was accomplished. Totem Exploration Co. of Ketchikan has been very active in looking for copper prospects in the southern part of the Panhandle.

Nickel. The Admiralty-Alaska Gold Mining Co. is still exploring its much-publicized deposit at Funter Bay on Admiralty Island. The large Yakobi Island deposits that were in dispute for so many years finally saw an intensive drilling program by the Devamin Co. in 1958, but results or future plans are not yet known. An interesting belt of nickel deposits extends from Yakobi Island south along the west coasts of Chichagof and Baranof Islands to Snipe Bay. Some activity was noted at the Spirit Mountain occurrence in the Copper River country, and another interesting nickel prospect is in the Salcha River area, held by Dean Ricks.

Tin. Tin is found in placer deposits in many locations in Alaska but the Seward Peninsula is the area of most importance. Lode tin deposits are common there and considerable tin placer mining has been done in the past. However, because of economic conditions, all placer tin mining has been at a standstill since 1953, and the only significant lode operation that has ever existed under the U. S. flag was forced to close in 1955. This was the U. S. Tin Corp. mine at Lost River. It was supported by government loans. The mine has since been offered for sale at auction, but the government repurchased it because of lack of suitable bids. Large placer tin reserves were outlined by drilling near Cape Mountain in 1952 and 1953, and make an attractive-appearing mining possibility, but no action has been taken. Placer tin has also been found in the Hot Springs District, Melozitna District, Fairbanks District, and others. Many years ago, a piece of tin "float" was found along Lynn Canal in Southeastern Alaska, indicating a possible source of lode tin somewhere in that country.

Mercury. There is quite a belt of cinnabar prospects extending from around the Red Devil mine near Sleetmute on the Kuskokwim River to the Marsh Mountain prospect near Dillingham. High mercury prices have kept exploratory and prospecting activities in this belt at a fairly high level, but the Red Devil remains the only producer except the one-man operation of Russel Schaefer on Cinnabar Creek. Sunshine Mining Co. spent both years drilling a mercury prospect near Kagati Lake in the Goodnews Quadrangle and the Cordero Mining Co. investigated certain prospects. One significant new discovery was made in 1958.

Tungsten. The Alaska Metals Mining Co. continued work throughout the biennium on its tungsten property at Gilmore Dome in the Fairbanks District. The mill that was built there in 1956 was not put into production because of the withdrawal of the tungsten price support in 1957. Rehabilitation work was continued by Hyder Mines, Inc. at the Riverside Mine in the Hyder District. Tungsten, in the form of scheelite, is found in gold placer deposits in various sections of Alaska.

Chromium. The Kenai Chrome Co., a major chrome producer, shut down its operation early in 1958 upon expiration of the government purchase program. The company was left holding several thousand tons of ore and concentrates which it had thought would be purchased. Bill Lyons made a small shipment in 1957. Seldovia Chrome Co. was not active in 1958. The chromite has all come from the Red Mountain area near Seldovia, but other chromite is known to exist on Baranof Island in Southeastern Alaska, near the Richardson Highway south of Tonsina, and other localities. 
Molybdenum. This metal, too, is found in nearly every section of Alaska. Two or three of the prospects may have commercial importance. Representatives of Climax Molybdenum Co. staked a likely prospect in Glacier Bay, but their future plans are not known.

Lead and Zinc. Though many claims continue to be located for these metals, particularly on silver-lead prospects, there was little activity beyond the claim staking. The main hope for lead or zinc mining in Alaska is that there will be sufficient silver or copper with it to "sweeten" it enough to pay the transportation bill. Two silver-lead prospects were explored in the Fairbanks District, and Neal W. Foster of Nome did some drilling on a silver-lead prospect on the Seward Peninsula.

Antimony. No antimony was produced during the biennium. Mr. Pilgrim did not do any further work at the Stampede Mine. With antimony deposits in all sections of Alaska, a good market would doubtless create many small antimony mining enterprises.

Barium. Deposits of barite are located in Southeastern Alaska in the Petersburg and Ketchikan Districts, but are somewhat small. A new barite discovery was made during the biennium in the Third Division that may prove to be significant.

Bismuth. A bismuth prospect exists in the Nome District.

\section{Nonmetallics}

Little has happened in nonmetallics during the biennium. Alaska has deposits of asbestos, mica, sulfur, and others, but the demand and interest in these seem to be slipping. Also in Alaska are deposits of jade, pumice, graphite, building stone of many types, silica, rare earths, gypsum, and unlimited reserves of high-calcium limestone. Other deposits include garnet, marble, fluorite, calcite, kyanite, and bentonite. Interest in gem stocks and suitable lapidary materials continues to grow, and the market for jewelry materials, as well as mineral specimens, from Alaska is improving steadily.

The best mica deposits known so far are found on Sitklan Island, south of Ketchikan, and on the Seward Peeninsula. Two promising vermiculite prospects were examined in 1958 by Department engineers. Although preliminary testing shows that

material is not of the highest quality, these prospects mav still be of commercial importance. Vermiculite can be expanded into a thermal insulating material, for which there is a good market in Alaska. Asbestos deposits are fairly wide spread, but the Kobuk River asbestos is the best known to date. Sulfur exists in innumerable pyrite deposits about Alaska, and in volcanic sulfur deposits along the Alaska Peninsula and Aleutian Islands. After drilling for three years on two sulfide properties on Latouche Island in Prince William Sound, Northern Pyrites Co. dropped its option.

The only known Alaska jade is found in good quantities along the Kobuk River in the Shungnak District. The Empire Jade Co. has been making' shipments from there, and Alfred Wolk of Skagway shipped 3,400 pounds for cutting and polishing. Pumice has not been mined for light weight aggregates lately, though it is available near Mt. Katmai on the shore of Cook Inlet.

\section{Coal}

A total of 13 coal mines were active during the biennium of which four were underground, two were one-man operations, and two were subcontractors to the Evan Jones mine. A list of the operators by name and address, etc., will be found in the last part of the report. With oil production approaching, and much talk of hydro projects and atomic reactors, the future of the coal mines is in doubt.

Matanuska Field. The Evan Jones Coal Co. continued its large underground operation and subcontracted two stripping operations to Wes Edwards and Minor Roop. Mrak Coal Co. operated on a larger scale than before. Paul Omlin and Rudy Sterbenz found two beds of exceptionally clean high-grade semibituminous near Chickaloon and formed the Castle Mountain Coal Co. to mine it. Pioneer Mining Co. changed hands and resumed operations at the old Premier Mine late in 1958.

Nenana Field. Suntrana Mining Co. mined coal from its underground mine throughout the biennium. Usibelli Coal Mine mined steadily but discontinued the underground part of its operation during 1958. Cripple Creek Coal Co. did not have sufficient coal contracts to keep it in operation for the full biennium, and Arctic Coal Co. mined intermittently. Usibelli established a retail outlet in Fairbanks in a laudable effort to improve 
its coal sales to the individual consumer. A mine-mouth power plant has been considered seriously for the Nenana Field which would be a boon to the coal miners and the consumers alike. Power would be transmitted to Fairbanks.

Kenai Field. Two strip pits near Homer were operated occasionaly by Jack Gist and Bruno Augustino.

Point Barrow Field. The Meade River Coal Mine continued to operate to provide coal for the residents of Point Barrow until late in the biennium. It was reported at that time that gas from the Naval Petroleum Reserve No. 4 was piped into the village so that the coal would no longer be needed. Report wes in error.

Broad Pass Field. A shipment of 26 tons of beneficiated coal to Fairbanks for testing purposes was made by Mrs. W. E. Dunkle from coal beds in this field developed by the late W. E. "Bill" Dunkle.

Bering River Field. Great interest is being shown in the possibilities of this undeveloped field for mining and shipping coking coal to Japan. A group of Japanese engineers, geologists, and industrialists visited the field with Alaskan engineers and representatives of the Jewell Ridge Coal Co. of Virginia, which is presently shipping coal to Japan from the East Coast. Negotiations are proceeding toward a several-hundred-thousand-dollar exploration project to determine if a large-scale mining and shipping operation can be made economically feasible.

Beluga Field. Preliminary investigations by the Department of Mines and U.S.B.IM. have shown that some large coal beds exist in this field that should provide for economical mining operations. Exploration work is contemplated by the U.S.B.M

\section{Radioactives}

Alaska's place in the ranks of uranium producers was shortlived. Climax Molybdenum Co. and prospectors Don Ross and Kelly Adams formed the Kendrick Bay Mining Co. to mine the deposit discovered by Ross and Adams in 1955. A 13/4 mile road was built to the property on Mt. Bokan at 1,000 feet elevation during June and part of July 1957, and the deposit was mined by open pit methods until October of that year. The ore was shipped to the uranium mill at Ford, near Spokane, Washington.
The operation was not resumed. Production records have not been made public.

Interest in uranium has been on the wane for some years, and is noted only occasionally at present. Southeast Mining and Exploration Co. drilled their prospect near William Henry Bay on Lynn Canal in the Juneau District in 1957, but results were not encouraging. An improved market or a big discovery are probably the only things that will revive a lively interest in Alaskan radioactives.

\section{Oil and Gas}

So much has happened in this category during the biennium that space is not available in this report to do it justice. Oil and gas will probably be the subject of a separate annual report from now on, whether by this agency or a new one created for that branch of the mineral industry. Only the highlights of Alaskan oil and gas developments for the biennium will be given here. The active companies are listed in the last part of the report.

Twelve wells were completed or being drilled during the biennium. Phillips Petroleum Co. finished Sullivan No. 2 (its third well) in March 1957, abandoned it as a dry hole, and ceased operations completely in that area, which was near Icy Bay and Yakataga on the Alaska Gulf Coast.

Standard Oil Co. of California and Richfield Oil Co. together drilled Swanson River No's. 1, 2, and 3 in the Swanson River Unit, Kenai Peninsula, of which the first two wells are producers and were undergoing production tests at the close of the biennium. No. 3 was abandoned as a dry hole. No. 4 is about to be drilled in the same area. No's. 5 and 6 are also planned for the same vicinity. Deep Creek No. 1 was drilled by the same companies south of the Kenai Moose Range wherein lie the others, but was abandoned as a dry hole.

Colorado Oil and Gas Corp. was drilliing its third well Yakutat No. 3 near that town, at the close of the biennium. High gas pressures were encountered in the first two but no appreciable oil shows were reported.

Humble Oil and Refining Co. and Shell Oil Co.. have been drilling Bear Creek Unit No. 1 on the Alaska Peninsula near Puale 
(Cold) Bay since September 1957. Much trouble has been encountered in this well and several million dollars have been spent on this one hole thus far. Drilling is presently approaching target depth.

Alaska Oil and Gas Development Co. and Aledo Oil Co. worked intermittently at continuing the drilling started near Eureka in 1953. Anchorage Gas and Oil Development Co. drilled intermittently in the Rosetta No. 3 near Houston on the Alaska Railroad. Late in the biennium, Alaska Consolidated Oil and Gas Co. moved into the old Havenstrite camp at Iniskin on the Alaska Peninsula and started drilling a new well there. The spudding-in time was 2 A.M., Christmas morning.

During the summer of 1958 , it was reported that at least 17 oil companies had geological and geophysical exploration parties in the field. These parties were using more than 50 helicopters. Countless miles of aeromagnetic surveys were flown by aeromag crews. No portion of Alaska that is in a sedimentary basin or a possible oil province is being overlooked. About one-third of the State's 375 million acres is considered as possibly oil-bearing. At the close of the biennium Standard Oil of California and several other companies announced plans to proceed immediately with water-borne seismic exploration operations which will cover all of the submerged lands beneath Cook Inlet north of Homer.

Various pieces of Federal legislation were passed affecting oil and gas operations in Alaska during the biennium. A law was passed that raised the rental fees and royalty rates to the government from oil and gas leases, and at the same time raised Alaska's share of such receipts to $90 \%$. It was made legal to lease lands beneath nontidal navigable waters. In the midst of Richfield and Standard's drilling program on the Kenai Moose Range, wildlife ranges were closed to oil and gas operations. This resulted in the Deep Creek Unit well being drilled while waiting to do more work on the Swanson River Unit. When the Range was reopened, half of it was, and still is, withheld from mineral production.

The PLO 82 area, consisting of 25,000,000 acres surrounding the Pet 4 area on the Arctic Slope, was opened to leasing except for 5 million acres in the northeast corner of Alaska, which, with another 4 million acres immediately to the south of it is being withheld pending a decision to make a 9 million acre withdrawal for an Arctic Wildlife Refuge. Part of the known Gubik Gas Field in the vicinity of Umiat, is in the opened area, and competitive bidding was held for 26 parcels of land on this structure. Alaska Propane Co. of Fairbanks was high bidder on most of the parcels. This company has a franchise for construction of a pipeline to Fairbanks from the Gubik for the transmission of gas for local consumption. This will be a tremendous undertaking, if the decision is made to proceed with the construction.

The Alaska Oil and Gas Conservation Commission held hearings and promulgated rules and regulations governing oil and gas production practices in the interest of conservation. The Alaska Department of Lands also held hearings and is now preparing its rules, regulations, and procedures for leasing of oil and gas lands which will be acquired by the State.

In the meantime, the companies and the public have been frantically applying for oil and gas leases at the Anchorage and Fairbanks offices of the U. S. Bureau of Land Management. At the end of the bienium, a total of 40 to 45 million acres have been applied for and leases on about half of this acreage have been granted. 


\section{EMPLOYMENT AND ACCIDENTS AT MINES}

\section{Employment and Nonfatal Accidents}

The following Table III reveals the trend of employment in the mining industry from 1914, the first year for which records are available, through 1958. Accidents and employment at the various types of mines are shown for each year of the biennium in Table IV. In this table, the accident figures for the placer operations other than dredging are not wholly accurate, for the accident reporting by the smaller operators is not complete. Table $\mathrm{V}$ indicates the number of man-shifts, accidents, and resulting time lost at different types of mines in Alaska for all the years for which records are available.

Coal mining being the most hazardous of the various types, particular care is taken in noting accident trends in that field. Comparative nonfatal coal mine accident statistics for the biennium follow:

\begin{tabular}{|c|c|c|c|}
\hline $\begin{array}{l}\text { Underground } \\
\text { Strip }\end{array}$ & \begin{tabular}{c} 
Man Shifts \\
$\quad 64,250$ \\
\hdashline$-. \quad 68,951$
\end{tabular} & $\begin{array}{c}\text { Nonfatal } \\
\text { Accidents } \\
74 \\
84\end{array}$ & $\begin{array}{l}\text { Accidents } \\
\text { Per M.M.H. } \\
143 \\
152\end{array}$ \\
\hline Total Alaska & 133,201 & 158 & 147 \\
\hline
\end{tabular}

Fatalities

Seven fatalities occurred in mines during the biennium, all of them in 1957. Of the seven deaths, six were in underground coal mines and one in an underground metal lode exploration project. Of the six coal fatalities, five were simultaneous in the worst Alaskan mining disaster for many years. Investigations revealed the following facts:

Philip V. Doherty, John E. Fowler, Sam Kwamdahl, Nick Uzelac, and Glen R. Vore, died January 18, 1957 in the Evan Jones Coal Company mine at Jonesville. The miners were killed by flame and forces of an underground explosion set off by an underburdened shot in the presence of an explosive mixture of methane and air and/or coal dust. The explosion was propagated by methane and coal dust.

Joe T. Peltola was fatally injured December 11, 1957 in the
Suntrana Mine at Healy River. After waiting for smoke to clear from a blast, Peltola and his partner started back to the working place. For some unknown reason, and against previous warnings, Peltola travelled by a different route through a place where the roof coal had been working and was considered unsafe. A fall of the roof injured him so badly that he died enroute to the hospital.

Samuel W. Elsom was killed April 18, 1957 in the AdmiraltyAlaska nickel property at Funter Bay, Chichagof Island. The accident occurred in a large exploratory drift which was being driven. The victim was operating a mucking machine when a roof fall killed him. He had been previously advised to bar down the overhead rock, as it looked dangerous, but had not taken the time to do so. 
TABLE III

Employment at Mines, 1914 to 1958 Inclusive Number of Men Employed at:

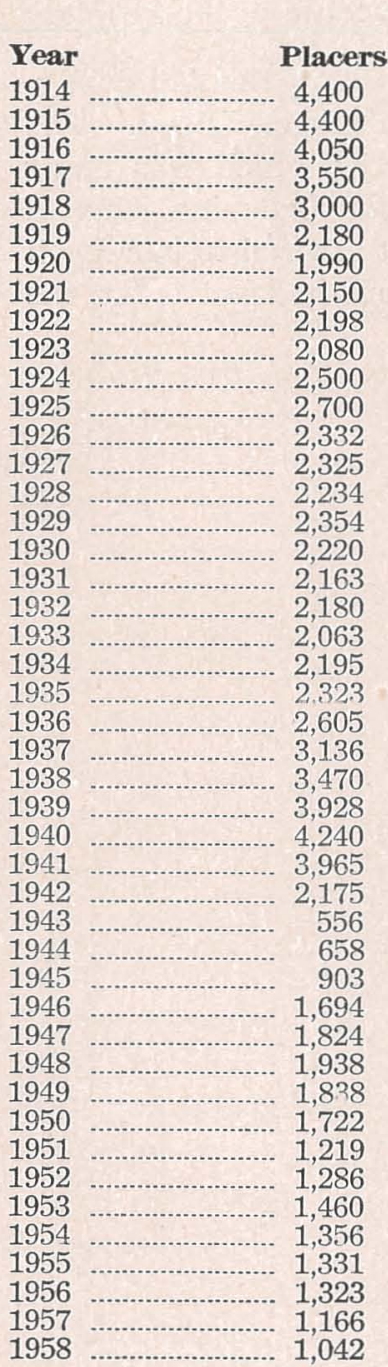

$\begin{array}{cc}\begin{array}{c}\text { Lode Mines and } \\ \text { Milling Plants }\end{array} & \begin{array}{c}\text { Coal and } \\ \text { other Mines }\end{array} \\ 3,500 & 140 \\ 3,850 & 160 \\ 4,200 & 340 \\ 3,220 & 270 \\ 1,897 & 400 \\ 1,757 & 310 \\ 1,880 & 360 \\ 1,681 & 400 \\ 1,623 & 280 \\ 1,500 & 270 \\ 1,978 & 175 \\ 1,745 & 116 \\ 1,663 & 108 \\ 1,930 & 114 \\ 1,668 & 109 \\ 1,605 & 89 \\ 1,502 & 98 \\ 1,323 & 78 \\ 1,496 & 78 \\ 1,246 & 68 \\ 1,451 & 79 \\ 1,665 & 89 \\ 1,867 & 105 \\ 1,957 & 92 \\ 2,071 & 218 \\ 1,986 & 229 \\ 1,974 & 149 \\ 1,805 & 218 \\ 1,065 & 249 \\ 581 & 312 \\ 489 & 393 \\ 238 & 309 \\ 446 & 334 \\ 384 & 280 \\ 309 & 267 \\ 262 & 323 \\ 243 & 297 \\ 202 & 287 \\ 222 & 404 \\ 270 & 394 \\ 299 & 345 \\ 420 & 287 \\ 386 & 282 \\ 415 & 314 \\ 276 & 286 \\ & \\ & \\ & \end{array}$

TABLE IV

Summary of Accidents and Employment at Mines in Alaska 1957-1958

(1957)

\begin{tabular}{|c|c|c|c|c|c|c|}
\hline $\begin{array}{l}\text { Num } \\
\text { Mir }\end{array}$ & S Group & $\begin{array}{l}\text { Number } \\
\text { of Men } \\
\text { Employed }\end{array}$ & $\begin{array}{l}\text { Number } \\
\text { Shifts } \\
\text { Viorked }\end{array}$ & $\begin{array}{r}\text { Re } \\
\text { Ac } \\
\text { Fatal }\end{array}$ & $\begin{array}{l}\text { sults of } \\
\text { cidents } \\
\text { Nonfatal }\end{array}$ & $\begin{array}{l}\text { Total } \\
\text { Time Lost } \\
\text { Days }\end{array}$ \\
\hline $\begin{array}{l}22 \\
78 \\
14 \\
17 \\
19\end{array}$ & $\begin{array}{l}\text { PLACER MINES } \\
\text { Dredges } \\
\text { Nonfloat } \\
\text { Hydraulic } \\
\text { Small scale hand } \\
\text { Others* }\end{array}$ & $\begin{array}{l}785 \\
284 \\
25 \\
20 \\
52\end{array}$ & $\begin{array}{r}178,800 \\
39,200 \\
2,080 \\
2,200 \\
4,730\end{array}$ & $\begin{array}{l}0 \\
0 \\
0 \\
0 \\
0\end{array}$ & $\begin{array}{r}186 \\
2 \\
0 \\
0 \\
0\end{array}$ & $\begin{array}{r}804 \\
2 \\
0 \\
0 \\
0\end{array}$ \\
\hline 150 & COAL MINES: & 1,166 & 227,010 & 0 & 188 & 806 \\
\hline $\begin{array}{l}4 \\
8\end{array}$ & $\begin{array}{l}\text { Underground } \\
\text { Strip }\end{array}$ & $\begin{array}{l}157 \\
157\end{array}$ & $\begin{array}{l}36,231 \\
35,606\end{array}$ & $\begin{array}{l}6 \\
0\end{array}$ & $\begin{array}{l}48 \\
50\end{array}$ & $\begin{array}{r}1,004 \\
971\end{array}$ \\
\hline 12 & LODE MINES: & 314 & 71,837 & 6 & 98 & 1,975 \\
\hline $\begin{array}{r}115 \\
2\end{array}$ & $\begin{array}{l}\text { Metal } \\
\text { Nonmetal }\end{array}$ & $\begin{array}{r}395 \\
2\end{array}$ & $\begin{array}{r}44,400 \\
240\end{array}$ & $\begin{array}{l}1 \\
0\end{array}$ & $\begin{array}{r}26 \\
0\end{array}$ & $\begin{array}{r}171 \\
0\end{array}$ \\
\hline 117 & MILIS: & 397 & 44,640 & 1 & 26 & 171 \\
\hline 2 & Metal ... & 18 & 4,920 & 0 & 11 & 244 \\
\hline 281. & Totals & $.1,895$ & 348,407 & 7 & 323 & 3,196 \\
\hline
\end{tabular}

PLACER MINES:

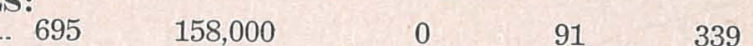

79 Nonfloat …......... $242 \quad 33,400$

$\begin{array}{llll}11 & \text { Hydraulic } \ldots \ldots . . . . . & 39 & 3,240 \\ 16 & \text { Small scale hand } & 18\end{array}$

17 Others* ${ }^{*}$

$\overline{145}$

1,042

$\overline{200,990}$

Underground .... $139 \quad 28,019$

Strip ……........... $147 \quad 33,345$

$\overline{12}$

LODE MINES: 28

$\overline{61,364}$

Metal $^{* *}$

31,700

2

$\overline{106}$

\section{MILLS:}

$\begin{array}{r}264 \\ -. \quad 2 \\ \hline\end{array}$

Metal $\quad 10 \quad 10 \quad 3,000$

264 Totals …1......1,604 297,294

Includes prospect

$$
\text { tion, and }
$$

Includes prospectors, exploration, and intermittent operations.

of List of Alaska of placer mining classifications, see footnote at end 
TABLE V

Summary of Man-Shifts Worked, Fatal and Nonfatal Accidents, and Time Lost in All Mines in Alaska

\begin{tabular}{|c|c|c|c|c|c|c|c|c|c|c|c|c|}
\hline & $\mathrm{Ma}$ & n-Shifts Wor & at & & Fatalities & & Non & fatal Accide & nts & Time & Lost & S) \\
\hline & Placer & Lode Mines & Coal & Placer & Lode Mines & Coal & Placer & Lode Mines & ; Coal & Placer I & Lode Mines & Coal \\
\hline Year & Mines & and Mills & Mines & Mines & and Mills & Mines & Mines & and Mills & Mines & Mines & and Mills & Mines \\
\hline $\begin{array}{l}1912 \\
1913\end{array}$ & & & & $\begin{array}{r}\mathbf{b} \\
10\end{array}$ & $\begin{array}{r}6 \\
15\end{array}$ & & & & & & & \\
\hline 1914 & & & & 5 & 14 & & & & & & & \\
\hline 1915 & & & & 4 & 19 & & & & & & & \\
\hline 1916 & & & & 7 & 22 & & 27 & 736 & & & & \\
\hline 1917 & & & & 9 & 24 & & 11 & 705 & & & & \\
\hline 1918 & & & & 1 & 12 & & 0 & 199 & & & & \\
\hline 1919 & & & & 0 & 13 & & 5 & 350 & 5 & & & \\
\hline 1920 & & & & 0 & 9 & & 0 & 302 & & & 2,831 & \\
\hline 1921 & & 568,615 & 103,389 & 0 & 12 & & 0 & 249 & & & 3,519 & 471 \\
\hline 1922 & & 537,180 & 55,309 & 0 & 5 & 0 & 0 & 252 & & & 4,344 & 250 \\
\hline 1923 & 84,948 & 618,359 & 66,927 & 2 & 9 & 0 & 7 & 230 & 42 & 394 & 3,991 & 673 \\
\hline 1924 & 117,545 & 468,890 & 51,398 & $\overline{0}$ & 16 & 0 & 30 & 327 & 6 & 560 & 4,882 & 75 \\
\hline 1925 & 405,000 & 592,326 & 34,353 & 0 & 6 & 0 & 0 & 303 & 5 & No report & t 5,639 & 109 \\
\hline 1926 & 418,744 & 563,992 & 51,398 & 1 & 6 & 1 & 90 & 365 & 10 & 1,042 & 5,308 & 75 \\
\hline 1927 & 418,235 & 555,155 & 34,915 & 2 & 7 & 1 & 178 & 259 & 13 & 3,267 & 4,819 & 445 \\
\hline 1928 & 445,707 & 559,081 & 32,766 & 3 & 6 & 0 & 152 & 302 & 2 & 2,048 & 5,981 & 19 \\
\hline 1929 & 420,249 & 524,836 & 25,525 & 5 & 9 & 0 & 142 & 255 & 6 & 1,657 & 4,301 & 197 \\
\hline 1930 & 484,301 & 486,515 & 30,101 & 0 & 7 & 0 & 123 & 271 & 7 & 1,096 & 3,979 & 221 \\
\hline 1931 & 437,573 & 425,201 & 22,129 & 0 & 6 & 0 & 92 & 167 & 5 & 1,251 & 2,668 & 101 \\
\hline 1932 & 441,335 & 445,876 & 22,267 & 0 & 5 & 0 & 67 & 163 & 14 & 765 & 2,630 & 250 \\
\hline 1933 & 437,267 & 403,021 & 19,805 & 1 & 7 & 0 & 90 & 177 & 2 & 1,077 & 2,381 & 9 \\
\hline 1934 & 478,908 & 443,265 & 20,514 & 0 & 6 & 0 & 95 & 220 & 7 & 1,313 & 3,784 & 201 \\
\hline 1935 & 499,765 & 458,440 & 23,571 & 2 & 6 & 0 & 116 & 266 & 12 & 1,250 & 4,372 & 291 \\
\hline 1936 & 496,370 & 515,105 & 27,285 & 2 & 8 & 0 & 89 & 284 & 8 & 1,014 & 3,780 & 149 \\
\hline 1937 & 547,748 & 548,929 & 25,267 & 2 & 2 & 16 & 129 & 298 & 14 & 1,733 & 5,007 & 407 \\
\hline 1938 & 607,624 & 595,520 & 27,744 & 2 & 5 & 0 & 112 & 351 & 20 & 1,365 & 5,091 & 423 \\
\hline 1939 & 683,624 & 548,121 & 26,643 & 1 & 3 & 0 & 158 & 302 & 15 & 2,263 & 4,247 & 488 \\
\hline 1940 & 718,153 & 552,579 & 34,450 & 4 & 4 & 0 & 162 & 313 & 29 & 1,999 & 4,260 & 721 \\
\hline 1941 & 657,142 & 517,347 & 54,779 & 1 & 1 & 0 & 151 & 325 & 38 & 1,978 & 5,069 & 630 \\
\hline
\end{tabular}

\begin{tabular}{|c|c|c|c|c|c|c|c|c|c|c|c|c|}
\hline 1942 & 358,185 & 300,785 & 68,593 & 2 & 2 & 2 & 72 & 149 & 41 & 1,129 & 3,002 & 746 \\
\hline 1943 & 82,780 & 155,370 & 84,694 & 0 & 3 & 1 & 1 & 82 & 37 & 54 & 1,338 & 635 \\
\hline 1944 & 98,117 & 81,246 & 101,609 & 0 & 1 & 0 & 0 & 18 & 89 & 0 & 386 & 2,057 \\
\hline 1945 & 145,260 & 52,224 & 84,523 & 0 & 0 & 3 & 5 & 2 & 64 & 22 & 10 & 1,417 \\
\hline 1946 & 297,529 & 116,670 & 82,303 & 0 & 1 & 1 & 44 & 12 & 75 & 521 & 131 & 952 \\
\hline 1947 & 351,916 & 85,361 & 80,691 & 1 & 1 & 1 & 65 & 8 & 47 & 869 & 110 & 646 \\
\hline 1948 & 390,566 & 66,602 & 74,273 & 0 & $\overline{0}$ & $\overline{1}$ & 55 & 7 & 48 & 1,003 & 322 & 613 \\
\hline 1949 & 361,494 & 54,796 & 86,602 & 0 & 0 & 0 & 59 & 12 & 66 & 538 & 427 & 1,292 \\
\hline 1950 & 343,974 & 52,850 & 70,364 & 0 & 0 & 1 & 38 & 14 & 63 & 656 & 596 & 941 \\
\hline 1951 & 222,577 & 33,035 & 66,985 & 1 & 0 & 0 & 45 & 1 & 66 & 402 & 10 & 834 \\
\hline 1952 & 246,065 & 40,060 & 85,438 & 1 & 0 & 0 & 27 & 0 & 88 & 200 & 0 & 904 \\
\hline 1953 & 284,390 & 34,490 & 112,636 & 1 & 1 & 2 & 53 & 12 & 160 & 616 & 98 & 2,049 \\
\hline 1954 & 265,820 & 43,410 & 81,049 & 1 & 3 & 1 & 46 & 20 & 71 & 374 & 190 & 1,048 \\
\hline 1955 & 253,220 & 62,460 & 76,449 & 0 & 1 & 0 & 154 & 6 & 82 & 944 & 138 & 574 \\
\hline 1956 & 252,005 & 61,900 & 79,489 & 0 & 1 & 0 & 124 & 32 & 74 & 918 & 317 & 691 \\
\hline 1957 & 227,010 & 49,560 & 71,837 & 0 & 1 & 6 & 188 & 37 & 98 & 806 & 415 & 1,975 \\
\hline 1958 & 200.990 & 34,940 & 61,364 & 0 & 0 & 0 & 93 & 10 & 60 & 341 & 111 & 815 \\
\hline
\end{tabular}




\begin{tabular}{|c|c|c|c|c|}
\hline Name and Address of Operator & Location of Mine & $\begin{array}{l}\text { Recording Precinct } \\
\text { and } \\
\text { (USGS Quadrangle) }\end{array}$ & $\begin{array}{l}\text { Type of } \\
\text { Operation }\end{array}$ & rox. \\
\hline $\begin{array}{l}\text { Admiralty Alaska Gold Mining Co. } \\
\text { Box 2642, Juneau }\end{array}$ & $\begin{array}{l}\text { Funter Bay } \\
\text { Admiralty Dist. }\end{array}$ & $\begin{array}{l}\text { Juneau } \\
\text { (Juneau) }\end{array}$ & $\begin{array}{l}\text { Nickel-copper lode } \\
\text { development }\end{array}$ & 4 \\
\hline $\begin{array}{l}\text { Alaska Exploration \& Mining Co. } \\
\text { Dorothy Wolfe-Trepte } \\
\text { Box 136, Pullman, Wash. or } \\
\text { Talkeetna }\end{array}$ & $\begin{array}{l}\text { Bird Creek } \\
\text { Yentna Dist. }\end{array}$ & $\begin{array}{l}\text { Talkeetna } \\
\text { (Talkeetna) }\end{array}$ & Hydraulic & 1 \\
\hline $\begin{array}{l}\text { Alaska Juneau Gold Mining Co. } \\
\text { Box 2419, Juneau }\end{array}$ & $\begin{array}{l}\text { A. J. Mine, Juneau } \\
\text { Juneau Dist. }\end{array}$ & $\begin{array}{l}\text { Juneau } \\
\text { (Juneau) }\end{array}$ & $\begin{array}{l}\text { Gold lode and mill } \\
\text { (selling equipment and } \\
\text { scrap) }\end{array}$ & 21 \\
\hline $\begin{array}{l}\text { Alaska Metals Mining Co., Inc. } \\
\text { Box 2051, Fairbanks }\end{array}$ & $\begin{array}{l}\text { Gilmore Dome } \\
\text { Fairbanks Dist. }\end{array}$ & $\begin{array}{l}\text { Fairbanks } \\
\text { (Fairbanks) }\end{array}$ & $\begin{array}{l}\text { Tungsten exploration and } \\
\text { mill construction }\end{array}$ & 3 \\
\hline $\begin{array}{l}\text { Alaska Nickel Co. } \\
\text { Fred Jenkins, Eagle }\end{array}$ & $\begin{array}{l}\text { Flume Cr. } \\
\text { Eagle Dist. }\end{array}$ & $\begin{array}{l}\text { Fairbanks } \\
\text { (Eagle) }\end{array}$ & Gold lode development & 5 \\
\hline $\begin{array}{l}\text { Alder Creek Mining Co. } \\
\text { Box 1999, Fairbanks }\end{array}$ & $\begin{array}{l}\text { Fairbanks Cr. } \\
\text { Fairbanks Dist. }\end{array}$ & $\begin{array}{l}\text { Fairbanks } \\
\text { (ilivengood) }\end{array}$ & Nonfloat & 8 \\
\hline $\begin{array}{l}\text { **Alluvial Golds, Inc. } \\
4732-46 \text { th N.E. Seattle } 5 \text {, or } \\
\text { Coal Creek }\end{array}$ & $\begin{array}{l}\text { Woodchopper Cr. } \\
\text { Circle Dist. }\end{array}$ & $\begin{array}{l}\text { Fairbanks } \\
\text { (Charley River) }\end{array}$ & Gold dredge & 19 \\
\hline
\end{tabular}

\section{Type of}

Nickel-copper lode

Hydraulic

Gold lode and mill (selling equipment and scrap)

ungsten exploration and 3 $\checkmark$ Amero, A. W. Chandalar

Anaconda Company, The Box 1764, Spokane 10, Wash.

*Anchorage Mineral Development and Exploration Co., Anchorage Ronald Trumbell

\section{Anderson, Ellis Chandalar}

Anderson, Tury and Associates Fairbanks

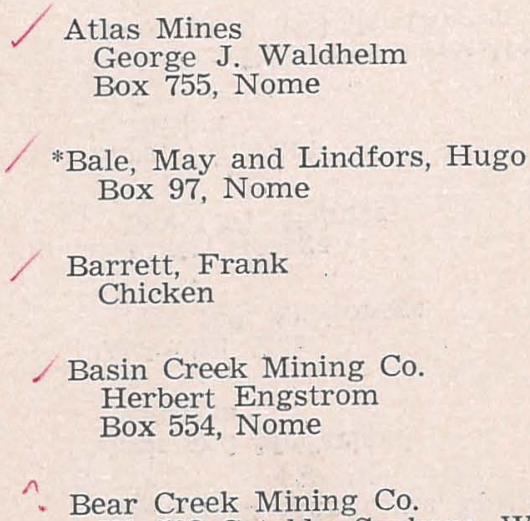

? Bear Creek Mining Co.

W. 508 Cataldo, Spokane, Wash. Shungnak Dist.
East Fork Chandalar

River

Chandalar Dist.

Alaska general

Grubstake Cr.

Chistochina Dist.

Tobin $\mathrm{Cr}$.

Chandalar Dist.

Kougarok Dist.

Dahl Cr.

Kougarok Dist.

Iron $\mathrm{Cr}$.

Nome Dist.

Mosquito Fork

Fortymile Dist.

Basin Cr.

Nome Dist.

Ruby $\mathrm{Cr}$ 


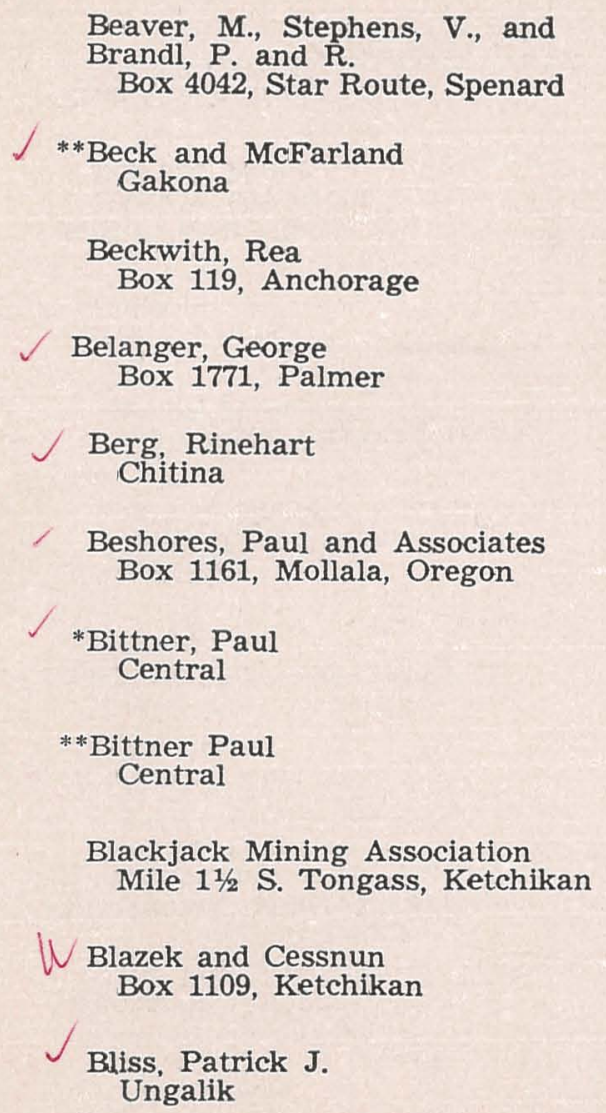

Beaver, M., Stephens, V., and Brandl, P. and R. Box 4042, Star Route, Spenard

$\int * *$ Beck and McFarland Gakona

Beckwith, Rea Box 119, Anchorage

$\checkmark$ Belanger, George Box 1771, Palmer

$\checkmark$ Berg, Rinehart Chitina

- Beshores, Paul and Associates Box 1161, Mollala, Oregon

*Bittner, Paul Central

**Bittner Paul

Central

Blackjack Mining Association Mile $1 \frac{11}{2}$ S. Tongass, Ketchikan

W Blazek and Cessnun Box 1109, Ketchikan

$\checkmark$ Bliss, Patrick J. Ungalik

Nugget Cr.
Yentna Dist.

Slate $\mathrm{Cr}$.

Chistochina Dist.

Alaska general

Nelchina Dist.

Ruby Cr.

Shungnak Dist.

Kugruk River

Fairhaven Dist.

Deadwood Cr.

Circle Dist.

Hot Springs Dist.

Southeast Alaska

Southeast Alaska

Ungalik Cr. Koyuk Dist.
Talkeetna

(Talkeetna)

Nonfloat

Chitina

(Mt. Hayes)

Nonfloat

10

Several

Chitina

(Talkeetna Mts.)

Noatak-Kobuk (Ambler River)

Fairhaven (Bendeleben)

Fairbanks (Circle)

Hot Springs

(Tanana)

Several

Several

Cape Nome (Norton Bay)
Mineral investigations

Prospecting

Copper lode development 1

Nonfloat

Hydraulic

Prospecting

Prospecting

Air and ground pros- 1 pecting

Nonfloat

3

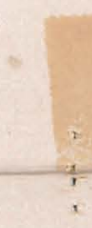

*Bodis, George Box 64, Nome

Bogan, P. W., and Massoz, G.B. Box 1354, Seward

Bolyan, George and Helen Cobol

*Bowman, Jack Reagan Hotel, Ketchikan

Breen, Amos 643-3rd Ave., Fairbanks

Breseman, John W. Box 796, Pelican

*Bronnicke, Fred Chistochina

Brown, Erwin General Delivery, Petersburg

Brown, Walter Hyder

**Bruce, F. L. and Cunningham, Al Mosquito Cr. Chicken

Fortymile Dist.

Crooked $\mathrm{Cr}$ Kantishna Dist.

Bryan Cr.

Kougarok Dist.

East Point Mine

Hope Dist.

Chichagof Dist.

Ketchikan Dist.

Circle Dist.

Chichagof Dist.

Ahtell $\mathrm{Cr}$.

Chistochina Dist.

Southeast Alaska

Hyder Dist.

Burnette, Dewey and Hunter, Martha Box 1995, Fairbanks

$\begin{array}{lll}\begin{array}{l}\text { Cape Nome } \\ \text { (Bendeleben) }\end{array} & \text { Nonfloat } & 1 \\ \begin{array}{l}\text { Seward } \\ \text { (Seward) }\end{array} & \text { Gold lode } & 2 \\ \begin{array}{l}\text { Sitka } \\ \text { (Sitka) }\end{array} & \text { Prospecting } \\ \begin{array}{l}\text { Ketchikan } \\ \text { (Ketchikan) }\end{array} & \text { Prospecting } & 1 \\ \begin{array}{l}\text { Fairbanks } \\ \text { (Circle) }\end{array} & \text { Lode prospecting } \\ \text { Sitka } & \text { Prospecting } & 1 \\ \begin{array}{l}\text { Chitina } \\ \text { (Gulkana) }\end{array} & \text { Lode gold prospecting } & 1 \\ \text { Several } & & 1 \\ & \text { Prospecting } \\ \begin{array}{l}\text { Hyder } \\ \text { (Ketchikan) }\end{array} & \text { Prospecting } \\ \begin{array}{l}\text { Fairbanks } \\ \text { (Eagle) }\end{array} & \text { Nonfloat } \\ \begin{array}{l}\text { Fairbanks } \\ \text { (Mt. McKinley) }\end{array} & \text { Nonfloat } \\ & & 2 \\ \end{array}$




$* *$ Burns, Joseph
Anchorage
Canyon Creek Mining Co.
Jens Kvamme \& Sons, Akiak
Carstens, Heine C.
Central
Carter and Love
Box 945, Ketchikan
Casanoff, Jack
Kiana
Cassell, J. B.
Hollis
Casto, Steve
33 Mile, Haines
Chandalar Mining Co.
Hugh Matheson, Jr.
613-3rd Ave., Anchorage
Chappell, Oliver L.
Wiseman
Chatham Creek Mining Co.
Berg, Tweiten, and Wickstrom
Box 64, Fairbanks
Box 64, Fairbanks
Hunter Cr.
Rampart Dist.

Dan Cr.

Nizina Dist.

Marvel Cr.

Aniak Dist.

Portage $\mathrm{Cr}$.

Circle Dist.

Ketchikan Dist.

Klery Cr.

Kiana Dist.

Hollis

Ketchikan Dist.

Porcupine $\mathrm{Cr}$.

Juneau Dist.

Big Cr.

Chandalar Dist.

Thompson Gulch and Nolan Cr. Koyukuk Dist .

Last Chance, trib. to L. Eldorado Fairbanks Dist.
Rampart

(Tanana)

(McCarthy)

Kuskokwim

(Bethel)

Fairbanks

(Circle)

Several

Noatak-Kobuk

(Baird Mts.)

Ketchikan

(Craig)

Haines

(Skagway)

Fairbanks

(Chandalar)

Fairbanks

(Wiseman)

Fairbanks

(Livengood)
Nonfloat

Hydraulic

20.

Nonfloat

Nonfloat

Prospecting

Small scale hand

Prospecting

Small scale hand

Nonfloat

Hydraulic

2

펌

2 업

1

1

2

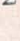

1

1.

4

Nonfloat

3
Chicken Hill Mines, Inc. Les Knappe, Chicken

Cleveland, Robert Shungnak

$\checkmark$ Cline, Harvey Cordova

$\checkmark$ Collinsville Mines, W. W. Renfrew 1557 H Street, Anchorage

Columbia Iron Mining Co. 525 William Penn Place Pittsburgh $30, \mathrm{~Pa}$.

7

Conkle, Earl J., and Associates Box 423, Ketchikan

Connell, Paul A. Central

Cordero Mining Co. 131 University Ave. Palo Alto, Calif.

? * Coronado Copper and Zinc Co. 209 Tabor Bldg., Wallace, Idaho

$\checkmark$ Crane, Fred and Associates Kotzebue Northern Alaska Regions

$\checkmark$ "Crook and Dodson Fairbanks
Northwestern and

Lost Chicken Hill

Fortymile Dist.

Shungnak River

Shungnak Dist.

Yakataga Beach

Yakataga Dist.

Mills and Twin Crs.

Yentna Dist.

Southeast Alaska

Clover Pass

Circle and Black Dists.

Aniak Dist.

Tungsten Hill

Fairbanks Dist.
Ketchikan Dist.
Eairbanks

(Eagle)

Noatak-Kobuk

(Shungnak)

Cordova

(Bering Glacier)

Talkeetna

(Talkeetna)

Several

Ketchikan

(Ketchikan)

Fairbanks

Circle and

Charley River)

Several

Several

Noatak-Kobuk (Several)

Fairbanks (Fairbanks)
Nonfloat

Jade placer

1

Small scale hand

1

Placer prospecting

2

Mineral investigation, aerial recon., drilling.

Prospecting and lode exploration

Prospecting

Mercury lode exploration 3

Mineral investigations and exploration

7

Prospecting

2

Tungsten lode development 


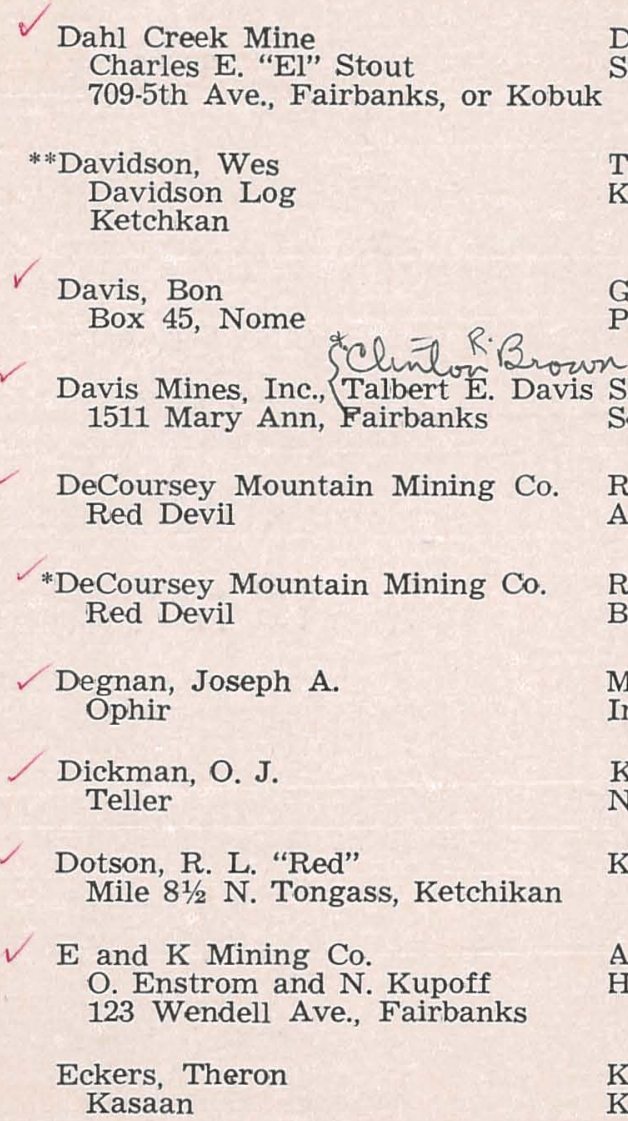
Charles E. "El" Stout Shungnak Dist.

1511 Mary Ann, Fairbanks Selawik Dist.
Dahl Cr.

Thorne River Ketchikan Dist.

Gold Run

Port Clarence Dist.

Red Devil Mine

Aniak Dist.

Red Top Mercury Property Bristol Bay Dist.

Madison $\mathrm{Cr}$. Innoko Dist.

Kigluaik Mtns. Nome Dist.

Ketchikan Dist.

American $\mathrm{Cr}$.

Hot Springs Dist.

Kasaan Peninsula Ketchikan Dist.
Noatak-Kobuk (Shungnak)

Nonfloat

Ketchikan

(Craig)

Prospecting

Cape Nome

(Teller)

Noatak-Kobuk

(Shungnak)

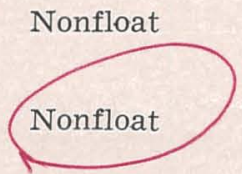

Kuskokwim

(Sleetmute)

Mercury lode and mill

Bristol Bay

(Dillingham)

Mercury lode development

Innoko

(Ophir)

Nonfloat

Cape Nome (Teller and Nome)

Several

Prospecting

Hot Springs

Nonfloat

(Tanana)

Ketchikan

(Craig)
4

2

1

1

Edgecumbe Exploration Co.
C. T. and G. H. Morgan
Box 758, Sitka
Edwards and Francis Co.
H. W. Edwards and Jack Francis
Box 513, Nome
Eisenmenger, William
410-11th St., Fairbanks
Emerick, Rollie
Delta Junction
Empire Jade Co.
Gene Joiner, Kotzebue
**Fairbanks Mining Co. of Alaska
$503-5$ th Ave., Fairbanks
Falls, Bentley
Box 33, Livengood
**Far North Mining and Develop-
ment Co.
Candle or Kotzebue
Flat Creek Placers
Fullerton Brothers, Flat
F lwarzney, John
Box 902, Ketchikan

Silver Bay

Chichagof Dist.

Solomon River

Tibbs Cr.

Goodpaster Dist.

Several

Jade Cr.

Kiana Dist.

Lookout Mine

Fairbanks Dist.

Wilbur Cr.

Tolovana Dist.

Candle Cr.

Flat $\mathrm{Cr}$

[ditarod Dist.

Helm Bav and

McLean Arm

Ketchikan Dist.
Sitka

(Sitka)

Gold lode maintenance

2

Cape Nome

(Solomon)

Nonfloat

3

Fairbanks

(Big Delta)

Lode prospect

Several

Prospecting

Noatak-Kobuk

(Ambler River)

Jade recovery and cutting

Fairbanks

(Fairbanks)

Lode prospect

Fairbanks

(Livengood)

Nonfloat

Fairhaven

(Candle)

Nonfloat

Mt. McKinley

Nonfloat

(Iditarod)

Ketchikan

(Craig and

Dixon Entrance)
Prospecting and lode exploration 


Foreman, Ken and Boedecker
Box 1543, Ketchikan
Foster, Neal W.
Box 279, Nome
*Frasca, John
Box 1182, Fairbanks
Fremont Mining Co.
Box 125, Forest Grove, Oregon
Gagnon Placers
Talkeetna
*Gangola, Joe
Route 1, N. Tongass, Ketchikan
Gearhart
Ghezzi, Alfred Sr.
Box 1857, Fairbanks
**Gilbertson, George, and Associates
Fairbanks
Gillette, B. F.
Box 285, Nome
* Gold Placers, Inc.
$4732-46 t h$ N.E., Seattle 5 , or
Coal Creek

Hollis

Ketchikan Dist.

Seward Peninsula

Several

Circle Dist.

First and Third Divisions

Cottonwood and

Willow Crs.

Yentna Dist.

Ketchikan Dist.

Camp Cr.

Fortymile Dist.

Third and Fourth

Divisions

Mosquito Fork

Fortymile Dist.

Anvil Bench

Nome Dist.

Coal Cr.

Circle Dist.
Ketchikan

(Craig )

Fairhaven and

Cape Nome

(Several)

Fairbanks

(Circle)

Several

Talkeetna

(Talkeetna)

Several

Fairbanks

(Eagle)

Several

Fairbanks

(Eagle)

Cape Nome

(Nome)

Fairbanks

(Charley River)
Prospecting

1 ल

Lode prospecting

1

Placer prospecting

Mineral explorations

1

14

Placer testing

2

Prospecting

Small scale hand

Prospecting

(1)

Nonfloat

Small scale hand

Gold dredge

5
Goldstream Mining Co. Denny G. Breaid

Box 2116, Fairbanks

Goodnews Bay Mining Co. 422 White Bldg., Seattle 1 , or Platinum

\section{Gordon, Tom}

Anchorage

Gouldsberry, Anson Seward

Grant Mining Co. Frank C. Edgington Box 53, Tanana

$\mathrm{H}$ and $\mathrm{T}$ Mining Co. Jack Haynes and Carl Thomas Box 1138, Seward

$\checkmark$ Hancock, K. S. Haines

Hansen ,Burnett F. Eagle

Hassel Mining Co. Harold Hassel Box 1071, Fairbanks

*Havenstrite Oil Co. Mining Division, Candle
Goldstream Cr.

Fairbanks Dist.

Salmon River and tribs. Goodnews Bay Dist.

Twin C

Yentna Dist.

Crown Point Mine

Hope Dist.

Grant Cr.

Melozitna Dist.

Last Chance Mine, Seward Seward Dist.

Porcupine Cr.

Juneau Dist.

Crooked Cr.

Eagle Dist.

Ready Bullion Cr.

Fairbanks Dist.

Candle Cr.

Fairhaven Dist.
Fairbanks

(Fairbanks)

Bethel

(Hagemeister Island)

Talkeetna

(Talkeetna)

Seward

(Seward)

Ft. Gibbon

(Melozitna)

Seward

(Seward)

Haines

(Skagway )

Fairbanks

(Eagle)

Fairbanks

(Fairbanks)

Fairhaven

(Candle)
Stripping only

1

Platinum dredge and nonfloat

40

Nonfloat

2

Gold lode development

Nonfloat

Gold lode preparation

2

Small scale hand

Nonfloat

Nonfloat

Nonfloat

20 


\begin{tabular}{|c|c|c|c|c|}
\hline $\begin{array}{l}\text { Havrilack, Harry } \\
\text { Rampart }\end{array}$ & $\begin{array}{l}\text { Ruby Cr. } \\
\text { Rampart Dist. }\end{array}$ & $\begin{array}{l}\text { Rampart } \\
\text { (Tanana) }\end{array}$ & Nonfloat & 1 \\
\hline $\begin{array}{l}\text { *Hayes, Howard } \\
\text { Box 1136, Douglas }\end{array}$ & Juneau Dist. & (Several) & Prospecting & 2 \\
\hline $\begin{array}{l}\text { *Heiner, Larry } \\
\text { Box } 182 \text {, Petersburg }\end{array}$ & $\begin{array}{l}\text { Petersburg and } \\
\text { Kupreanof Dists. }\end{array}$ & Seyeral & Prospecting & 1 \\
\hline $\begin{array}{l}\text { Herman, Bob } \\
\text { Box 163, Nome }\end{array}$ & $\begin{array}{l}\text { Darling Cr. } \\
\text { Nome Dist. }\end{array}$ & $\begin{array}{l}\text { Cape Nome } \\
\text { (Nome) }\end{array}$ & Nonfloat & \\
\hline $\begin{array}{l}\text { Hibbard, Bill } \\
\text { Box } 525 \text {, Craig }\end{array}$ & Ketchikan Dist. & Several & Prospecting & 1 \\
\hline $\begin{array}{l}\text { Hickok, Clara and Engelhorn, } \\
\text { Forest } \\
\text { Talkeetna }\end{array}$ & $\begin{array}{l}\text { Thunder Cr. } \\
\text { Yentna Dist. }\end{array}$ & $\begin{array}{l}\text { Talkeetna } \\
\text { (Talkeetna) }\end{array}$ & Hydraulic & 4 \\
\hline $\begin{array}{l}\text { *Hinchey, Ken } \\
1300 \text { A St., Anchorage }\end{array}$ & $\begin{array}{l}\text { Chisna River } \\
\text { Chistochina Dist. }\end{array}$ & $\begin{array}{l}\text { Chitina } \\
\text { (Mt. Hayes) }\end{array}$ & Nonfloat & 8 \\
\hline $\begin{array}{r}\text { *Hobb Enterprises, Inc. } \\
232 \text { B St., Anchorage }\end{array}$ & $\begin{array}{l}\text { Slate Cr. } \\
\text { Chistochina Dist. }\end{array}$ & $\begin{array}{l}\text { Chitina } \\
\text { (Mt. Hayes) }\end{array}$ & Nonfloat & 14 \\
\hline $\begin{array}{l}\text { **Hofstad, Richard } \\
\text { Petersburg }\end{array}$ & Petersburg Dist. & Several & Prospecting & 1 \\
\hline $\begin{array}{l}\text { Hogendorn, Jack } \\
\text { Deering }\end{array}$ & $\begin{array}{l}\text { Inmachuck River } \\
\text { Fairhaven Dist. }\end{array}$ & $\begin{array}{l}\text { Fairhaven } \\
\text { (Bendeleben) }\end{array}$ & Hydraulic & 1 \\
\hline $\begin{array}{l}\text { Hope Mine } \\
\text { R. V. Watkins } \\
\text { Box 521, Fairbanks }\end{array}$ & $\begin{array}{l}\text { Faith Cr. } \\
\text { Fairbanks Dist. }\end{array}$ & $\begin{array}{l}\text { Fairbanks } \\
\text { (Circle) }\end{array}$ & Nonfloat & 3 \\
\hline
\end{tabular}

Huff, and Caldwell 309 Buren, Ketchikan

**Humble Oil and Refining Co. 1829 E. 5th Ave., Anchorage

Hyder Mines, Inc. 904 Fourth Ave., Seattle or Hyder

- I-L \& M Co.

Box 2015, Ketchikan

$\checkmark$ **Inmachuck Mining Co. Grant H. Nelson Nome

Johansen, Engbert Chicken

Johnson, Iver M. Fairbanks

Johnson, John Box 2255, Ketchikan

Johnson, Pete Manley Hot Springs

$\checkmark \quad$ *Jurich, John and Carr, Tom Livengood

Gravina Island

Ketchikan Dist.

Bristol Bay Dist.

Riverside Mine

Hyder Dist.

Kendrick Bay and others

Ketchikan Dist.

Inmachuck River

Fairhaven Dist.

Ingle $\mathrm{Cr}$.

Fortymile Dist.

Chisana Dist.

Thorne Arm

Ketchikan Dist.

Eureka Cr.

Hot Springs Dist.

Lillian $\mathrm{Cr}$.

Tolovana Dist.

Red Mountain

Homer Dist.
Ketchikan

(Ketchikan)

Copper prospect

Bristol Bay

(Dillingham)

Iron lode exploration

10

Hyder

Silver-lead-tungsten

Bradfield Canal) lode preparations

2

Ketchikan

(Several)

Fairhaven

(Bendeleben)

Fairbanks

(Eagle)

Fairbanks

(Nabesna)

Ketchikan

(Ketchikan)

Hot Springs

(Tanana)

Fairbanks

(Livengood)

Seldovia

(Seldovia)
Air and ground prospect- 1 ing for uranium

Gold dredge

Small scale hand

Nonfloat

Prospecting

Small scale hand

Nonfloat

Chromium lode and mill 29 
* Kendrick Bay Mining Co. Mines Park, Golden, Colo. or Box 2189, Ketchikan

$\checkmark$ *Ketchum Creek Mining Co. Al Swatch Fairbanks

Kettendorf, James Box 657, Hagamon Road Fairbanks

**Kimball, John and Hamlin, Jack

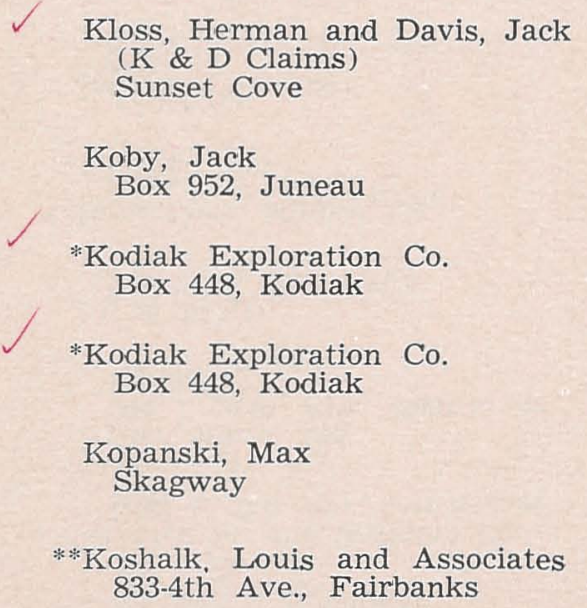

Kendrick Bay

Ketchikan Dist.

Ketchum Cr.

Circle Dist.

Rose Creek
Fairbanks Dist.
Eldorado and Whit
Valdez Creek Dist.
Sunset Cove
Petersburg Dist.
Juneau Dist.
Kodiak Island
Kodiak Dist.
Sitkalidak Island
Kodiak Dist.
Juneau Dist.
Crevice Cr., trib.
John River
Koyukuk Dist.

Ketchikan

(Dixon Entrance)

Uranium lode

15

Fairbanks

(Circle)

Nonfloat

1

Fairbanks

(Fairbanks)

Small scale hand

1

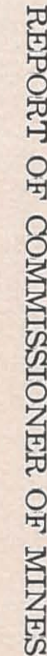

Kodiak

Skagway

(Skagway)

Fairbanks

(Wiseman)
Hydraulic

3

Gold-antimony lode devel- 2 opment and prospecting

Prospecting

Tungsten prospecting 3

Copper lode development 2

Prospecting

1

Nonfloat

3
Nonfloat 


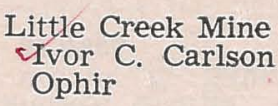

K. "Loken, K. H. and Bedlington, Dick 423-3rd St., Juneau

Lone Jack Mining Co.

David White

Hollis

Long Creek Mining Co. Robert Deacon Ruby

Little Cr.

Innoko Dist.

Third Division

Southeast Alaska

Hollis

Ketchikan Dist.

Long Cr.

Ruby Dist.

Mammoth $\mathrm{Cr}$.

Lucky Seven Mining Co.

Walter E. Roman, Miller House

Circle Dist.

$\checkmark \quad$ Lucky Syndicate A. L. Schneider and S. L Godfrey Box 615, Nome

Kougarok River

*Lucky Ten Associates 1112 Tongass, Ketchikan

Ketchikan Dist.

Red Mountain area

Homer Dist.

S. Fork Fortymile River Fortymile Dist.

Star Route, Anchorage

McCombe
Chicken

obert
Innoko

(Ophir)

Several

Several

Ketchikan

(Craig)

Nulato

(Ruby)

Fairbanks

(Circle)

Cape Nome

(Bendeleben

Several

Seldovia

(Seldovia)

Fairbanks

(Eagle)
Nonfloat

(n) 


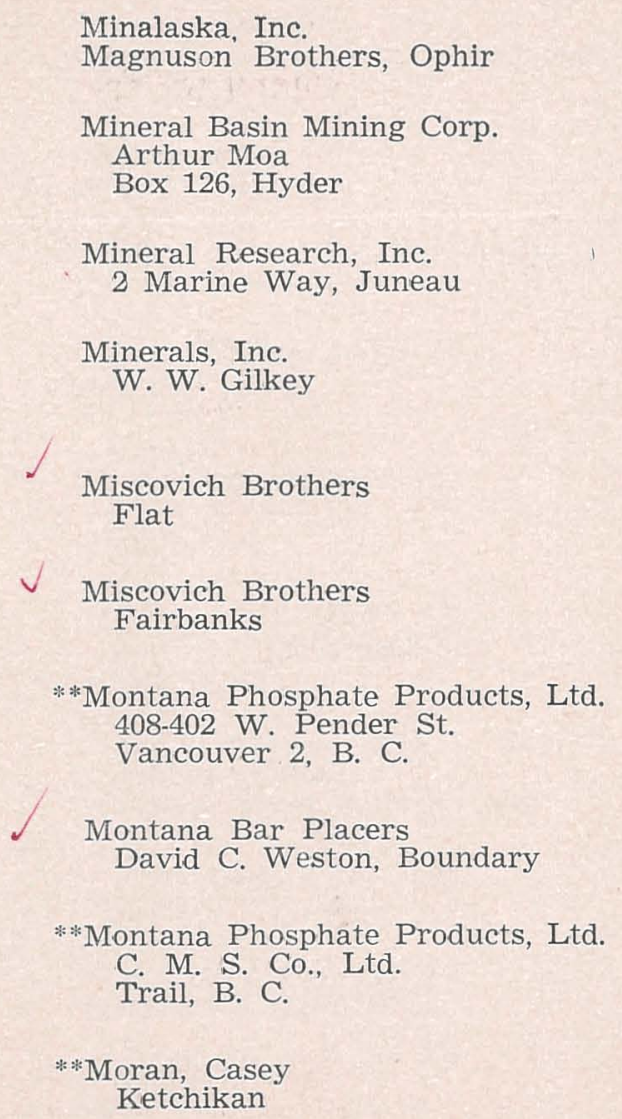
408-402 W. Pender St. Vancouver 2, B. C.

Montana Bar Placers David C. Weston, Boundary

**Montana Phosphate Products, Ltd. C. M. S. Co., Ltd. Trail, B. C.

**Moran, Casey Ketchikan

**Montana Phosphate Products, Ltd. Southeast Alaska Ketchikan Dist.
Innoko

(Iditarod)

Hyder

(Ketchikan)

Several

Juneau

(Yakutat and

Mt. Fairweather)

Mt. McKinley Nonfloat

(Iditarod)

Nulato

(Ruby)

Nonfloat

Several

Fairbanks

(Eagle )

Ketchikan

(Craig)

Ketchikan

(Craig) tions

Nonfloat

Nonfloat
Gold dredge

Lode exploration and prospecting

Air and ground

Beach placer investiga- 4

Mineral investigations and reconnaissance

Copper exploration H 


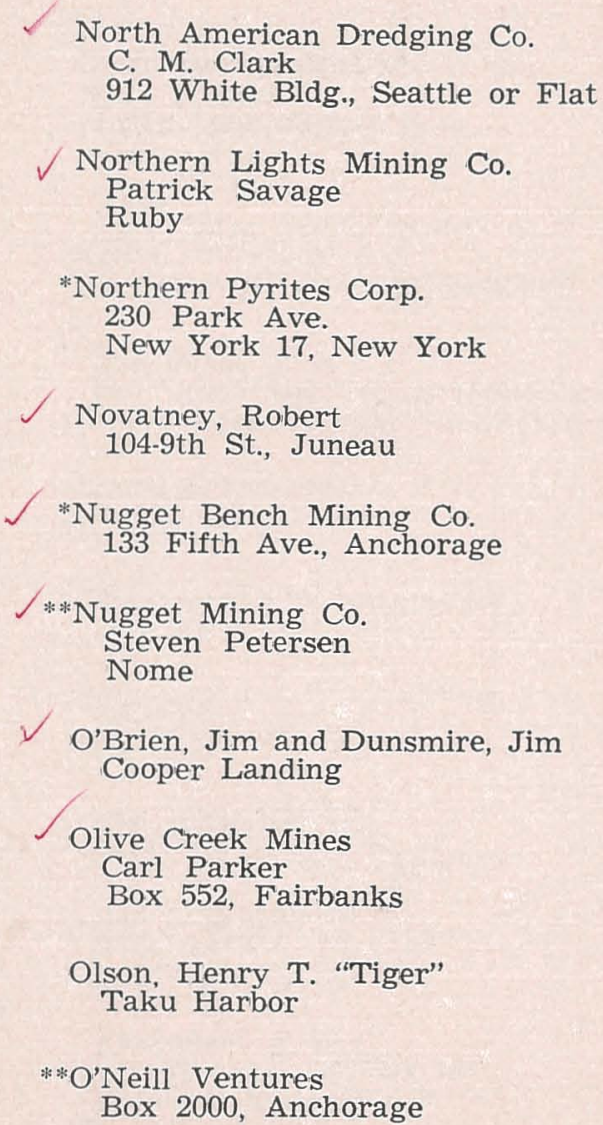

Flat $\mathrm{Cr}$ Iditarod Dist.

Long Cr.

Ruby Dist

Latouche Island

Prince William Sound Dist. (Seward)

Helm Bay

Ketchikan Dist.

Nugget Cr.

Yentna Dist.

Niukluk River

Council Dist.

Surprise Cr.

Hope Dist.

Little Eva Cr.

Fairbanks Dist.

Juneau and Admiralty

Dists.

Upper Falls Cr.

Yentna Dist.
Mt. McKinley (Iditarod)

Nulato

(Ruby)

Valdez

Ketchikan

(Ketchikan)

Talkeetna

(Talkeetna)

Cape Nome (Solomon)

Sewward

(Seward)

Fairbanks

(Fairbanks)

Juneau

(Sumdum)

Talkeetna

(Talkeetna)
Gold dredge

9

is

Nonfloat

5

Sulfide exploration, core drilling

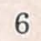

6

Gold lode development

1

Placer preparation

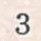

Gold dredge

4

Placer drift

Nonfloat

2

5

Prospecting

1

Placer exploration
*(Operator unknown)

Ott, Joe

Box 744, Pelican

Otter Dredging Co. Ogriz and Kobler Flat

Owens, J. E. 704-10th, Fairbanks

$\checkmark$ *Parker and Raymond Mining Co. Box 462, Fairbanks

$\checkmark$ Pekovich, W. S. Box 2642, Juneau

U. Petersburg Explorations Dave Ohmer Petersburg

Pettyjohn, Fred S. 4 Eleanor St., Fairbanks

W. Pieper and Eichner 2312 Tongass, Ketchikan

* Pioneer Exploration Co. Carl Bradley Box 125, Wrangell

*Polfus, Bernard and Associates $112 \frac{1}{2}-8$ th Ave., Anchorage
Grubstake Gulch Willow Cr. Dist.

\section{EI Nido property}

Chichagof Dist.

Otter Cr.

Iditarod Dist.

Sheenjek Dist.

Mastodon $\mathrm{Cr}$. Circle Dist.

Port Snettisham

Juneau Dist.

Southeast Alaska

S. Slope Alaska Range

Southeast Alaska

Southeast Alaska

Lewis River Redoubt Dist.
Wasilla

(Anchorage)

Sitka

(Sitka)

Mt. McKinley (Iditarod)

Fairbanks

Fairbanks

(Circle)

Juneau

(Sumdum)

Several

Talkeetna

(Several)

Several

Several

Anchorage (Tyonek)
Hydraulic 1

Gold and tungsten prospecting

Gold dredge

Prospecting

Nonfloat

Iron lode development

Air and ground prospecting

Lode prospecting

Copper and iron prospecting

1

1

엇

3

1

1

2

Air and ground prospecting

Nonfloat 


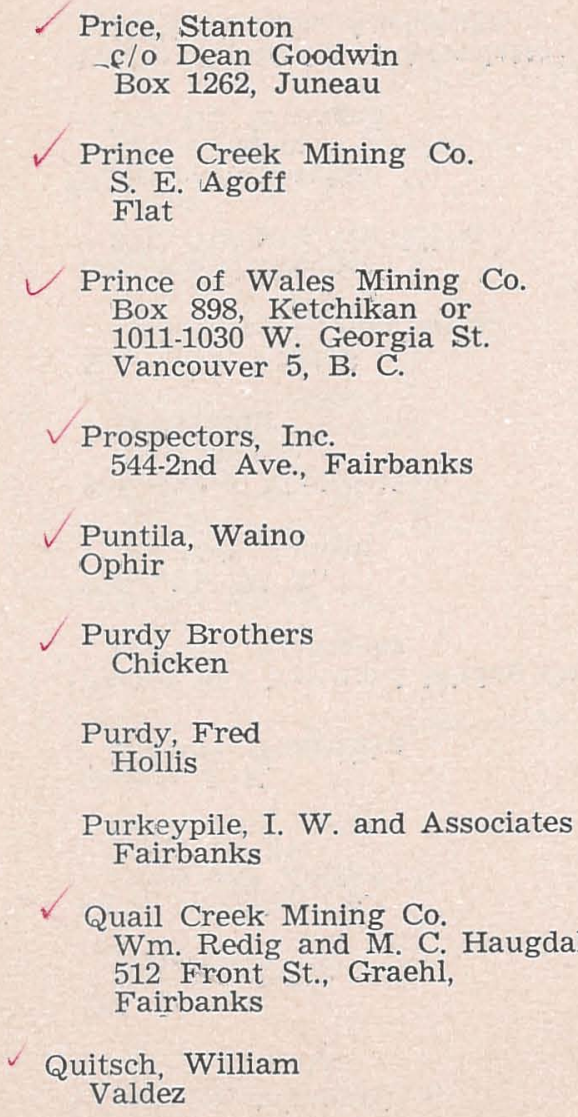

Mineral $\mathrm{Cr}$. Valdez Dist.

Myrtle Cr.

Koyukuk Dist.

Little Cr.

Innoko Dist.

Chicken Cr.

Fortymile Dist.

Hollis

Ketchịkan Dist.

Tonzona Dist.

Quail Cr.
Mt. McKinley

Nonfloat

4 (Iditarod)

Several

Mineral reconnaissance and prospecting

Fairbanks

(Chandalar)

Innoko

(Ophir)

Fairbanks

(Eagle)

Ketchikan

(Craig)

Mt. McKinley

(Talkeetna)

Rampart

(Livengood)

Prospecting

Nonfloat

Nonfloat

Prospecting

Lode prospecting

Nonfloat

4

牙

3

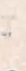

3

2

Gold lode

1

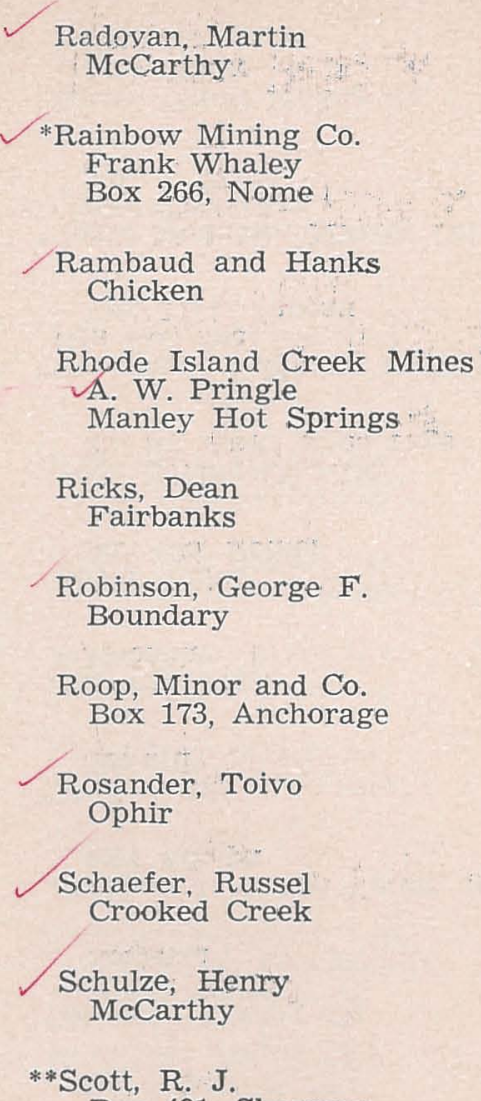

Glacier Cr.

Nizina Dist.

Grouse Cr.

Kougarok Dist.

Napoleon $\mathrm{Cr}$.

Fortymile Dist.

Rhode Island $\mathrm{Cr}$.

Hot Springs Dist

r.

Fairbanks Dist.

Wade Cr.

Fortymile Dist.

Valdez Cr.

Valdez Cr. District

Yankee Cr.

Innoko Dist.

Cinnabar $\mathrm{Cr}$.

Aniak Dist.

Vicinity of McCarthy

Nizina Dist.

Juneau Dist .
MeCarthy

(McCarthy)

Cape Nome

(Bendeleben)

Fairbanks

(Eagle)

Hot Springs

(Tanana)

sets:

Fairbanks

(Big Delta)

Fairbanks

(Eagle)

Talkeetna

(Healy)

Innoko,

(Iditarod)

Kuskokwim (Taylor Mtns.)

McCarthy (McCarthy)

Skagway (Skagway)
Copper lode prospecting 1

Nonfloat

2

Hydraulic

Nonfloat

Prospecting

Nonfloat

Placer testing and preparations

Nonfloat

Mercury lode

Copper lode development 1

Prospecting

1 


** Seely, Robert
*Seldovia Mining Co.
Frank Raby
Seldovia
Sheldon, John and Vetter, Rudy
and Adolph
*Shell, Louis
Seward
Shotter, Frank
Hoonah
Sirilo, Julius
Box 625, Bethel
*Sona Mining Co., Inc.
236-4th Ave., Anchorage
*Southeastern Mining and Explora-
tion Co., Inc.
Box 1121, Juneau
*Spirit Mountain Mining Co.
Ray Trotachau
Sultan, Wash.
Squaw Creek Mining Co.
Jack Wilke
Boundary

Fortymile River
Fortymile Dist.

Red Mountain area

Homer Dist.

Head of Bedrock Cr. Fairbanks Dist.

Canyon Cr.

Hope Dist.

Juneau and Sitka Dists.

Aniak Dist.

Pass Cr

Yentna Dist.

Near William Henry Bay Juneau Dist.

Canyon Cr. Nizina Dist.

Canyon Cr.

Fortymile Dist.
Fairbanks

(Eagle)

Seldovia

(Seldovia)

Fairbanks

(Livengood)

Seward

(Seward)

Several

Kuskokwim

Talkeetna

(Talkeetna)

Juneau

(Juneau)

Chitina

(Valdez)

Fairbanks

(Eagle)
Nonfloat

Chromium prospecting

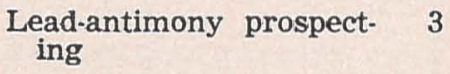

Hydraulic

3

Prospecting

1

Prospecting

1

Nonfloat

Uranium lode drilling

3

Nickel-copper prospecting 5

Nonfloat $\checkmark$

Stanich Brothers

Wiseman

**Steears, Al

**Stoakes, Charles Box 1619, Ketchikan

Strandberg Mines, Inc. 926-4th Ave., or Box 2099 Anchorage

Strandberg Mines, Inc. Box 2099, Anchorage

Strandberg Mines, Inc. Box 2099, Anchorage

Strandberg Mines, Inc. Box 2099, Anchorage

Strandberg Mines, Inc. Box 2099, Anchorage

Stuver, Jules Flat

* Sulgas Properties, Ltd. 604-744 W. Hastings St. Vancouver 1, B. C.

Sunshine Mining Co. 738 Peyton Bldg. Spokane 1, Wash.
Porcupine $\mathrm{Cr}$.

Koyukuk Dist.

Southeast Alaska

Moira Sound

Ketchikan Dist.

Alaska general

Eureka $\mathrm{Cr}$

Hot Springs Dist.

Indian River

Hughes Dist.

Colorado Cr.

Innoko Dist.

Iron $\mathrm{Cr}$.

Yentna Dist.

Marietta $\mathrm{Cr}$. Iditarod Dist.

Alaska general

Kagati Lake Bethel Dist.
Fairbanks

(Wiseman)

Several

Ketchikan

(Craig and

Dixon Entrance)

Several

Hot Springs

(Tanana)

Fort Gibbon Nonfloat

(Hughes)

Innoko

(Ophir)

Talkeetna

(Talkeetna Mtns.)

Mt. McKinley

(Iditarod)

Several

Bethel

(Goodnews Bay)
Mineral investigations

Nonfloat

Nonfloat

Nonfloat and placer drift 2

Prospecting

2

1

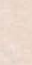

2

rospecting

Hydraulic

Mineral investigations

Mercury lode exploration 3 


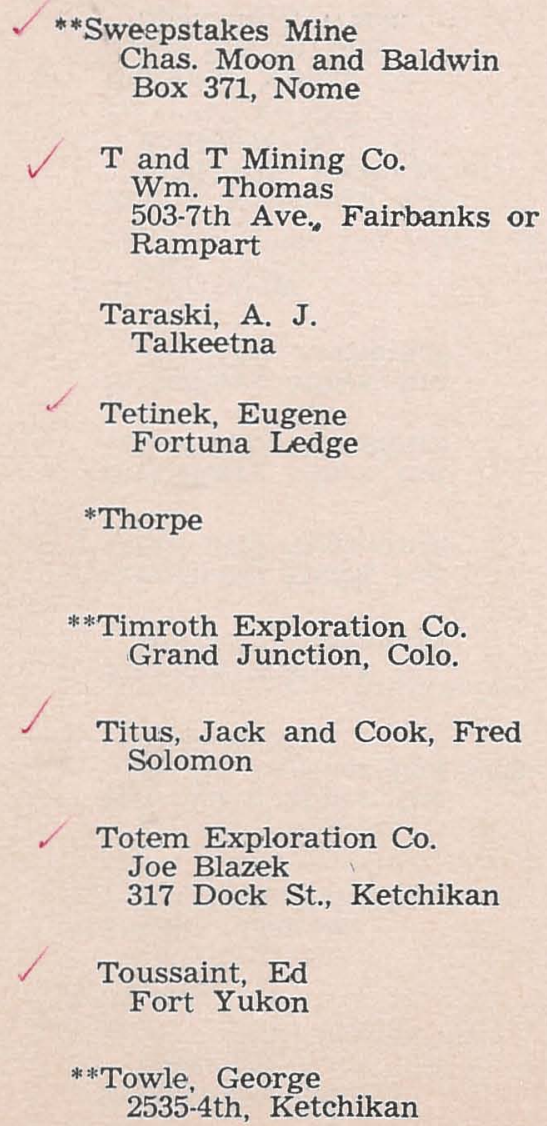

Sweepstakes Cr. Koyuk Dist.

Hunter Cr.

Rampart Dist.

Cache Cr. Yentna Dist.

Willow Cr. Marshall Dist.

Grubstake Gulch Willow Creek Dist.

Alaska general

Shovel Cr.

Nome Dist.

Southeast Alaska

Big Cr. Chandalar Dist.

Southeast Alaska
(Tanana)

Nonfloat

1

Cape Nome

Nonfloat

2

(Candle)

$\begin{array}{lll}\begin{array}{l}\text { Talkeetna } \\ \text { (Talkeetna) }\end{array} & \text { Placer prospecting } & 1 \\ \begin{array}{l}\text { Wade Hampton } \\ \text { (Russian Mission) }\end{array} & \text { Nonfloat } & 1 \\ \begin{array}{l}\text { Wasilla } \\ \text { (Anchorage) }\end{array} & \text { Gold lode } & 1 \\ \text { Several } & \text { Mineral explorations } & 5 \\ \begin{array}{l}\text { Cape Nome } \\ \text { (Solomon) }\end{array} & \text { Small scale hand } \\ \text { Several } & \text { Prospecting-exploration } \\ & \text { and diamond drilling } & 2\end{array}$

Fairbanks (Chandalar)

Gold lode development

1

Several

Aerial Magnetometer

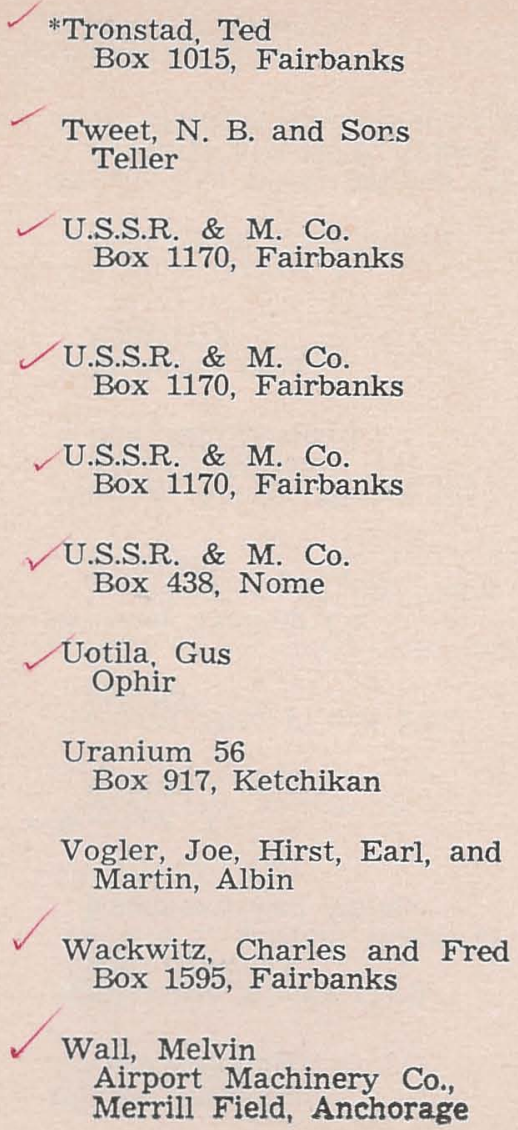

Dahl Cr.

Shungnak Dist.

Kougarok River Kougarok Dist.

Fairbanks Dist.

Hogatza River

Hughes Dist.

Mosquito Fork Fortymile Dist.

Nome Dist.

Ophir Cr.

Innoko Dist.

Southeast Alaska

Morelock Cr.

Rampart Dist.

Bedrock Cr. Fairbanks Dist.

Valdez Cr. Valdez Cr. Dist.
Noatak-Kobuk (Shungnak)

Cape Nome (Bendeleben)

Fairbanks (Fairbanks and Livengood)

Ft. Gibbon (Hughes)

Fairbanks

(Eagle)

Cape Nome (Nome)

Innoko

(Ophir)

Several

Rampart

(Tanana)

Fairbanks (Livengood)

Talkeetna (Healy)
Hydraulic (also jade recovery)

Nonfloat, hydraulic, and 6 dredge

6 gold dredges

350

Gold dredge

Stripping

3 Gold dredges

Nonfloat

Air and ground prospecting

Prospecting

Prospect development

Placer and lode prospect- 1 ing 
Watson Mrs, Ben

Cape Yakataga

Wattamuse Mining Corp.

Nat Browne,

Route 1, Burton, Wash. or

Goodnews Bay Village

**Weimer, J.

Central

$\checkmark$ Weinard, Otto F. and Fred Candle

Weisner Trading Co. Ira Weisner and Jim Pierce Rampart

$\checkmark$ Western Alaška Mining Co. R. J. Anderson Box 121, Spenard

Whitehead, Fred Boundary

$\checkmark$ Williams, Burton A. May Creek via Cordova

*Wilson and Drake Mining Co. C. Drake and W. L. Wilson 612 Gamble, Anchorage or Berry

Withrow, Alfred W. Bettles Field
Yakataga. Beach

Yakataga Dist.

Slate Cr

Goodnews Bay Dist.

Cordova

(Bering Glacier)

Bethel

(Goodnews)

Miller $\mathrm{Cr}$.

Circle Dist.

Fairbanks

(Circle)

Mud Cr.

Fairhaven Dist.

Eairhaven

(Candle)

Little Minook and Hoosier Rampart

Crs.

(Tanana)

Rampart Dist.

Kolmakof property

Aniak Dist.

Chicken Cr.

Fortymile Dist.

Rex Gulch

Nizina Dist.

Ester Dome

Fairbanks Dist.

Koyukuk River Koyukuk Dist.

Kuskokwim (Sleetmute)

Fairbanks

(Eagle)

McCarthy

(McCarthy)

Fairbanks

(Fairbanks)

Fairbanks

(Bettles)
Small scale hand

Nonfloat

Nonfloat

2

Nonfloat

5

Nonfloat

Mercury lode development

Nonfloat

2 ำ



5 Ix

画

Small scale hand

Gold lode prospect

Small scale hand 
$\checkmark$ Zurek, W. J. Miller House

Mastodon Cr. Circle Dist.

*1957 only

**1958 only

"Nonfloat" indicates mechanical placer gold operation using draglines and/or bulldozers to transport gravel to non-floating washing plant, bedrock sluiceboxes, or elevated sluices.

"Hydraulic" indicates placer gold operations in which gravel is excavated and transported to sluiceboxes solely by water jets from hydraulic nozzles.

"Small scale hand" indicates placer gold operation in which gravel excavation and transportation is accomplished by hand or ground sluicing.

ACTIVE COAL MINES, 1957-1958

Name and Address of Operator

Arctic Coal Co., Inc.

Box 1386, Fairbanks or Lignite

Augustino, Bruno
Box 23, Homer

Castle Mountain Coal Co.

Box 1292, Palmer

Cripple Creek Coal Co.

Box 529, Fairbanks

Edwards Strip

Subcontracting under Evan Jones

Evan Jones Coal Co.

Box 619, Anchorage or Jonesville

\section{Gist Strip Mine}

Jack C. Gist, Box 55, Homer

Meade River Coal Co.

Ed Burnell, Barrow

Minor Roop Strip

Subcontracting under Evan Jones

\section{Location of Mine}

Lignite $\mathrm{Cr}$.

Nenana Field

Near Homer

Kenai Field

Near Chickaloon Matanuska Field

Cripple Cr.

Nenana Field

Jonesville Mine

Matanuska Field

Jonesville Mine

Matanuska Field

Near Homer

Kenai Field

Meade River

Pt. Barrow Field

Jonesville Mine

Matanuska Field

\section{Mining District}

Type of

Operation

Approx.

Bonnifield Dist. Strip
(Healy)

(Healy)

Strip

Homer Dist.

(Seldovia)

Strip

Willow Cr. Dist.

Strip

Bonnifield Dist. Strip

(Healy)

(1)

Willow Cr. Dist. Strip

(Anchorage)

Willow Cr. Dist. Underground

(Anchorage)

Strip

Homer Dist.

Barrow Dist.

(Meade River)

Underground

Willow Cr. Dist. Strip

(Anchorage)
10

1

4

13

15

70

1

12

29 


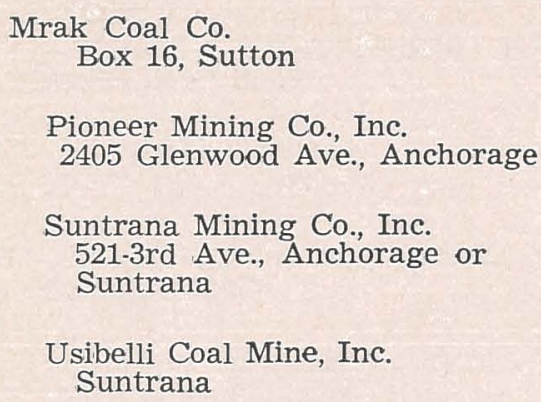

Near Eska

Matanuska Field

Premier Mine Matanuska Field

Healy Cr.

Nenana Field

Healy Cr.

Nenana Field
Willow Cr. Dist. Strip

(Anchorage)

Willow Cr. Dist. Underground

(Anchorage)

Bonnifield Dist. Underground (Healy)

53

Bonnifield Dist. Strip (Healy)

44

\section{OIL AND GAS COMPANIES ACTIVE DURING THE BIENNIUM, 1957-1958}

Name and Alaskan

Address of Company

Alaska Consolidated Oil Co., Inc.

Alaska Gulf Oil \& Gas Development, Inc.

Alaska Oil \& Gas Development Box 2000, Anchorage

Alaska Oil \& Mineral Co., Inc.

Alaska Propane Co., Inc.
208 Cushman St. or

Box 967, Fairbanks

Alaska Tidelands Oil Co., Inc.

First National Bank Bldg.

638 Fourth Ave., Anchorage

Alaska-Yukon Refiners \& Distributors, Ltd. c/o Walter Sczudlo

209 Lacey St., Fairbanks

Aledo Oil Co.

Amerada Petroleum Corp.
Home or Regional Office

80 Wall St., New York City 5,

6157 Collins St.

Pedley, California

Leasing

Drilling, associated with Aledo

80 Wall St., New York City 5,

Leasing

Leasing, preparing for drilling and gas pipeline

Leasing

Preparations for petroleum distribution

750 West Fifth St., Fort Worth 2,

Drilling, associated with Alaska Oil \& Gas Development 
Anchorage Gas \& Oil Develoment Co., Inc.

134 E. Second St., Anchorage

Anderson-Prichard Oil Corp.

Apache Oil Corp.

Ashland Oil \& Refining

Atlantic Refining Co., Inc.

Aztec Oil \& Gas Co.

Benedum, Paul G.

Bintliff, David C., Interests

Blackwell Oil \& Gas Co.

Bristol Bay Oil Co

British American Oil Producing Co.

Champlin Oil \& Refining Co.

Cities Service

Clark Oil \& Refining
Drilling

1000 Liberty Bank Bldg.

Leasing

Oklahoma City 2,

823 South Detroit Ave., Tulsi Leasing

Leasing

937 Atlantic Bldg. Leasing Box 2819, Dallas

920 Mercantile Securities Bldg. Leasing Dallas

Benedum-Trees Bldg., Pittsburgh 22 Leasing, geological

1312 Bank of the Southwest Building Leasing Houston

507 Enterprise Bldg., Tulsa $3 \quad$ Leasing

815 Sixth St. West, Calgary, Alberta Leasing

Mercantile-Dallas Bldg., Dallas

Geophysical

Box 9365, Fort Worth

Leasing

Leasing

Leasing
Colorado Oil \& Gas Corp. Yakutat

Continental Oil Co.

Cortez Oil Co.

Cosden Petroleum

Delhi-Taylor Oil Corp

El Paso Natural Gas Products Co.

Exploration Services, Inc Professional Bldg;

529 Sixth St., or

Box 2061, Fairbanks

Franco Western Oil Co.

Frankfort Oil Co.

\section{General Petroleum Corp. \\ Carrington Bldg. or \\ Box 1734, Anchorage}

Global Exploration Co.

Great Basins Petroleum Co.

Drilling, seismic work

1137 Wilshire Blvd., Los Angeles 17

1700 Broadway, Denver

Corrigan Tower, Dallas

Box 1161, El Paso

3132 Eighteenth St., Bakersfield

Davis Bldg., Dallas

612 South Flower St.

Los Angeles 54

800 Petroleum Club Bldg.

Denver 2

Suite 87, Quinby Bldg. 650 South Grand Ave., Los Angeles 17
Drilling, associated with Colorado Oil \& Gas

Leasing

Leasing

Leasing

Geophysical

Consulting

Leasing

Drilling, associated with Colorado Oil \& Gas

\section{Geophysical, associated with Great Basins}

Geophysical

Geophysical 
Halbouty Alaska Oil Co. (Halasko)
First National Bank Bldg., Anchorage

Hiawatha Oil \& Gas Co.

Home Oil Co., Ltd.

Honolulu Oil Corp.

Humble Oil \& Refining Co. 1829 East Fifth Ave., or

Box 248, Anchorage

Iniskin Unit Operator, Inc.

Kerr-McGee Oil Industries, Inc.

Kewanee Oil Co.

King Oil, Ine.

Monterey Oil Co.

Northern Development Co.
Halbouty Bldg.

5111 Westheimer Road, Houston 27

Petroleum Club Bldg., Denver

304 Sixth Ave., West

Calgary, Alberta

215 Market St., San Francisco 5

Humble Bldg., Box 2180, Houston

811 West Seventh, Los Angeles 17

Kerr McGee Bldg., Oklahoma City

1401 South Boulder or

Box 2239, Tulsa

Oil \& Gas Bldg.

Wichita Falls, Texas

550 South Flower St.

Los Angeles 17

Box 1413, Tacoma
Preparing to drill, associated with King

Leasing

Leasing

Leasing Drilling, geophysical, associated with
Shell

Leasing

Leasing

Leasing

Preparing to drill, associated with Halbouty

Leasing

Leasing
Ohio Oil Co.

$522 \mathrm{~K}$ Street, Anchorage

Pan American Petroleum Corp.

Phillips Petroleum Co.

Loussac Sogn Bldg.,

439 D St., Anchorage

Plymouth Oil Co.

Polaris Exploration Co., Inc. 306 B St., Anchorage

Pure Oil Co.

Reserve Oil \& Gas Co.

Richfield Oil Corp. Fifth Ave. \& E St., Anchorage

Shell Oil Co.

Signal Oil \& Gas

Sinclair Oil \& Gas Co.

Skelly Oil Co.

Snowden, James $\mathrm{H}$.
550 South Flower St.

Los Angeles 17

Box 591, Pan American Bldg., Tulsa 2

Bartlesville, Oklahoma

505 Eighth Ave., West Bldg. Calgary, Alberta

Geophysical, associated with Union

Geophysical

Leasing

Box 271, Tulsa

64 Pine St., San Francisco 11

555 South Flower St.

Los Angeles

Suite 1055, Dexter Horton Bldg. Seattle 4

Box 521, Tulsa

Box 1650 , Tulsa

750 West Fifth St., Fort Worth
Leasing

Leasing

Leasing

Leasing

Drilling, geophysical, associated with Standard of California

Drilling, geophysical, associated with Humble

Leasing

Geophysical

Leasing

Leasing 
Sohio Petroleum Co.

Standard Oil Co. of California 209 Fireweed Lane, Anchorage

Standard Oil (Ind.)

Standard Oil (N. J.)

Sun Oil Co.

Sunray Mid-Continent Oil Co. Carrington Bldg., or Box 854, Anchorage

Suntide Refining

Superior Oil Co.

T.U.L.M. Corp.

Texaco (Alaska), Inc. (The Texas Co.)

Texas National Petroleum Co.

Texota Oil Co.
1400 Skirvin Tower Hotel Oklahoma City

225 Bush St., San Francisco 20

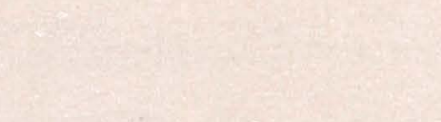

1608 Walnut St., Philadelphia 3

714 West Olympic Blvd. Los Angeles 15

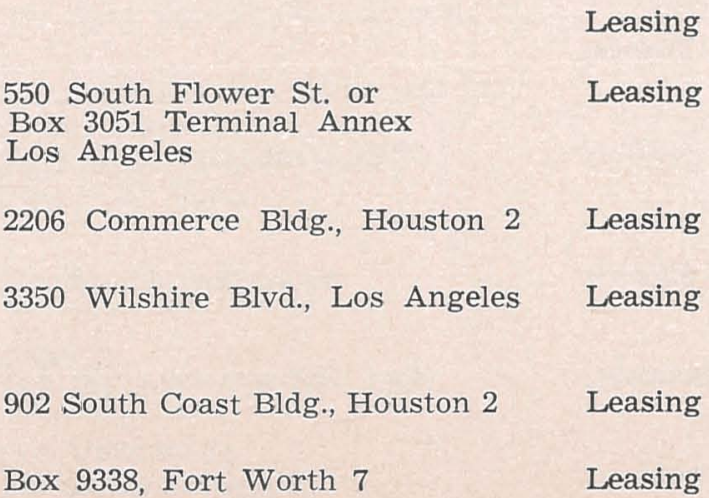

550 South Flower St. or

Box 3051 Terminal Annex

Leasing

Leasing

Leasing

Leasing

easing

easing

easing

easing

easing

Box 9338, Fort Worth 7
Leasing

Drilling, geophysical, associated with Richfield

Geophysical
Tidewater Oil Co.

Union Oil Co. of California Carrington Bldg. or Box 1872, Anchorage

Western Gulf Oil Co. Fourth Ave. Bldg., Anchorage

Yakutat Development Co.
4201 Wilshire Blvd., Los Angeles 5

Box 7600, Los Angeles 54

1200 Statler Center 900 Wilshire Blvd., Los Angeles 17

Wyatt Bldg., Washington, D. C. Leasing
Leasing

Geophysical, associated with Ohio

Geophysical 


\section{LISTS OF REPORTS ISSUED BY THE COMMISSIONER OF MINES AND CORRESPONDING PRECEDING OFFICIALS}

*Report of the Mine Inspector for the Territory of Alaska to the Secretary of the Interior, fiscal year ended June 30, 1912.

* Report of the Mine Inspector for the Territory of Alaska to the Secretary of the Interior, fiscal year ended June 30, 1913.

*Report of the Mine Inspector for the Territory of Alaska to the Secretary of the Interior, fiscal year ended June 30, 1914.

*Report of the Territorial Mine Inspector to the Governor of Alaska for the year 1915

*Report of William Maloney, Territorial Mine Inspector, to the Governor of Alaska for the year 1916.

*Report of the Territorial Mine Inspector to the Governor of Alaska for the year 1917.

*Annual Report of the Territorial Mine Inspector to the Governor of Alaska, 1920.

*Annual Report of the Territorial Mine Inspector to the Governor of Alaska, 1921.

*Annual Report of the Mine Inspector to the Governor of Alaska, 1922

*Annual Report of the Mine Inspector to the Governor of Alaska, 1923

*Report upon industrial accidents, compensation and insurance in Alaska for the biennium ending December 31, 1924

*Report of the Territorial Mine Inspector, calendar years 1925-26.

*Report of cooperation between the Territory of Alaska and the United States in making mining investigations and in the inspection of mines for the biennium ending March 31, 1929.

*Report of cooperation between the Territory of Alaska and the United States in making mining investigations and in the inspection of mine for the biennium ending March 31, 1931.

* Mining investigations and mine inspection in Alaska, biennium ending March 31, 1933

* Report of the Commissioner of Mines to the Governor, biennium ending December 31, 1936.

*Report of the Commissioner of Mines to the Governor, biennium ending December 31, 1938.

*Report of the Commissioner of Mines to the Governor, biennium ending December 31, 1940 .

*Report of the Commissioner of Mines to the Governor, two biennia ended December 31, 1944

Report of the Commissioner of Mines, biennium ended December 31, 1946

Report of the Commissioner of Mines, biennium ended December 31, 1948

Report of the Commissioner of Mines, biennium ended December 31, 1950
*Report of the Commissioner of Mines, biennium ended December 31, 1952. Report of the Commissioner of Mines, biennium ended December 31, 1954. *Report of the Commissioner of Mines, biennium ended December 31, 1956.

Joesting, Henry R., Strategic mineral occurrences in interior Alaska: Pamphlet No. 1, May 1942

* Joesting, Henry R., Supplemental to Pamphlet No. 1-Strategic mineral occurrences in interior Alaska: Pamphlet No. 2, March 1943.

*Andersen, Eskil, Mineral occurrences other than gold deposits in Northwestern Alaska: Pamphlet No. 5-R, May 1944.

*Stewart, R. L., Prospecting in Alaska (26-page pamphlet), December 1944. Revised to November 1949).

*Glover, A. E., Industrial minerals as a field for prospecting in Alaska, ncluding a glossary of elements and minerals (82-page booklet)

Anderson, Eskil, Asbestos and jade occurrences in the Kobuk River region, Alaska; Pamphlet No. 3-R, May 1945.

Roehm, J. C., Some high calcium limestone deposits in Southeastern Alaska; Pamphlet No. 6, March 1946.

Proper Claim Staking in Alaska; Information Circular No. 1, August 15, 1953.

Rights of Canadians in Alaska under the Mining Laws; Information Circular No. 2, September 15, 1953.

Hints for Prospectors on the Mainland of Southeastern Alaska; Information Circular No. 3, March 15, 1954.

*Alaska Uranium Information; Information Circular No. 4, March 15, 1955.

General Alaskan Mineral Information: Information Circular No. 5, March $15,1955$.

Alaskan Prospecting Information; Information Circular No. 6, April $15,1956$.

Compulsory Assesswork Work Affidavits; Information Circular No. 7, July 15,1957

*Out of print. On file in certain public and university libraries. 